Article

\title{
Optimization of MgO-GGBS Cementitious Systems Using Thermo-Chemical Approaches
}

\author{
Blessing Adeleke*(D), John Kinuthia (D) and Jonathan Oti
}

School of Engineering, Faculty of Computing, Engineering and Science, University of South Wales, Pontypridd CF37 1DL, UK; john.kinuthia@southwales.ac.uk (J.K.); Jonathan.oti@southwales.ac.uk (J.O.)

* Correspondence: blessing.adeleke@southwales.ac.uk; Tel.: +44-1443-482167

Citation: Adeleke, B.; Kinuthia, J.; Oti, J. Optimization of MgO-GGBS Cementitious Systems Using Thermo-Chemical Approaches. Sustainability 2021, 13, 9378. https:// doi.org/10.3390/su13169378

Academic Editor: Sergio Mendez

Received: 3 August 2021

Accepted: 19 August 2021

Published: 20 August 2021

Publisher's Note: MDPI stays neutral with regard to jurisdictional claims in published maps and institutional affiliations.

Copyright: (c) 2021 by the authors. Licensee MDPI, Basel, Switzerland. This article is an open access article distributed under the terms and conditions of the Creative Commons Attribution (CC BY) license (https:/ / creativecommons.org/licenses/by/ $4.0 /)$.

\begin{abstract}
The current study investigated the development of a sustainable thermo-chemical approach to effectively optimize MgO-waste activated GGBS formulations, using four types of magnesium oxide $(\mathrm{MgO})$ waste materials with ground granulated blast-furnace slag (GGBS) to develop binary cementitious systems (MgO-GGBS). This stems from the expected complexity of cementitious binder optimization outcomes into a simpler analytic form, enhancing the rapid delivery of optimization results and contributing to the global awareness of sustainable approaches and use of industrial wastes. Three levels of Portland cement by weight (90, 80, and $70 \mathrm{wt} . \%$ ) was replaced with $\mathrm{MgO}$ wastes including an industrial by-product (GGBS) to develop an experimental regime. Investigation was carried out by employing an experiment-based optimisation technique (thermo-chemical approach), which involved the design of an experimental regime and application of experimental tests ( $\mathrm{pH}$ measurements, thermogravimetric and derivative thermogravimetric analysis-TG/DTG and isothermal calorimetry), establishment of design variable/parameters, measurement of the design performance of the identified design parameters, and review of the relationship between the independent (control) and dependent variables ( $\mathrm{MgO}$ wastes and their compositions). The experimental test results successfully optimised the binder compositions, established the best performing binder system (MG1), and provided an in-depth insight into the thermal stability and hydration kinetics of the investigated binder systems.
\end{abstract}

Keywords: magnesium oxide waste; cementitious binder; industrial by-products; heat of hydration; isothermal calorimetry; thermogravimetry

\section{Introduction}

The production and application of new cementitious materials can be a cumbersome task in understanding and discovering an optimum mix composition. This is due to the virtually infinite number of possible binder compositions (different oxides stoichiometry) that could be investigated even if one is restricted to the main material oxides $(\mathrm{Ca}, \mathrm{MgO}$, $\mathrm{SiO}_{2}, \mathrm{Al}_{2} \mathrm{O}_{3}$, and $\mathrm{H}_{2} \mathrm{O}$ ) to produce calcium silicate hydrate (C-S-H) and magnesium silicate hydrate (M-S-H) precipitate amongst other formations [1-5]. Abdolhosseini Qomi et al. [6] suggested that small differences in the structure and composition could significantly impact on the properties of the developing binder systems. This could be further complicated based on the impact of the thermodynamic conditions $(\mathrm{pH}$, temperature, relative humidity, pressure, etc.) on the structure of the developed binders at varying compositions [7].

The traditional Edisonian technique for optimization constantly used by various researchers (i.e., adding varying/random fractions of SCMs to PC or MgO) based on a "trial-and-error" approach has been found to possess limited or inaccurate results, which will not likely result in further research discovery [8]. This necessitated the investigation and application of several systemic/theoretical optimisation techniques such as expert, algorithmic/mathematical (Tagushi, Maxwell, and PROMETHEE II method), and experiment-based optimisation techniques. The expert and algorithmic/mathematical 
(Tagushi, Maxwell, and PROMETHEE II method) technique has been reported to be often time-consuming, is critically reliant on the existence of large databases of reliable and consistent data that are presently lacking, and requires a step-by-step method for establishing the right mix composition and associated parameters to obtain the most effective blend system. However, the experiment-based optimisation technique could require a certain level of technical knowledge and expertise for its application [9-14]. The basic principle that underpins the experiment-based optimisation technique involves the design of an experimental regime and application of experimental tests (isothermal calorimetry, TG/DTG, and pH measurements), the identification and establishment the design variable/parameters with maximum and minimum limits, the measurement of the design performance of the identified design parameters (hydration kinetics etc.), and a review of the relationship between the independent (control) and dependent variables ( $\mathrm{MgO}$ wastes and their compositions). Recent investigations into the sustainable application of $\mathrm{MgO}$ for cementitious systems have shown its potential to mitigate the negative environmental impacts of PC $[2,15,16]$. Yi et al. [17] compared the use of $\mathrm{MgO}$ and PC for developing cementitious binder systems and found $70-72 \%$ less energy consumption, a $65-79 \% \mathrm{CO}_{2}$ emission reduction, and a 6-13\% reduction in the cost of $\mathrm{MgO}$ production compared to $\mathrm{PC}$.

Regarding the design parameters, it is worth noting that the performance of cementitious formulations has recently been found to be a key focal point of interest with respect to the monitoring of heat evolution during a hydration process. This stems from the hypothesis that the performance of cementitious systems could be predicted by monitoring the generated heat during hydration, which can be measured by a calorimeter [18]. Therefore, the heat of hydration, which is the integral of the heat production rate (thermal power) in a hydration process, is very essential for investigating hydration rates, variation in temperature changes within the cementitious binder composition, and classification of binder compositions based on their reactivity $[19,20]$. Some thermochemical approaches have been used to evaluate the hydration kinetics of Portland cement $[18,21,22]$. Nevertheless, the application of isothermal calorimetry, thermogravimetric and derivative thermogravimetric analysis (TG/DTG), and $\mathrm{pH}$ measurements for MgO-GGBS system have not been well-established in the existing literature for binder optimisation. Until now, most researchers have concentrated on the application of this experimental tool at a later stage of research for a predetermined mix composition, rather than the initial optimization of cementitious binder systems. Therefore, the laboratory tests will be employed as an optimization tool in the current study to further simplify the expected complexity of the optimisation of an emerging binder system (MgO-GGBS) into a simpler analytic form that can be examined from the laboratory tests.

The current study reports the outcome of a thermo-chemical optimisation approach, which was employed to establish the best performing MgO-waste:GGBS binder system developed from four (4) different types of MgO-waste material, upon inclusion with GGBS based on the aforementioned design parameters (intensity of heat of hydration, alkalinity levels, magnitude and duration of forming calorimetric peaks, type and magnitude of the formed hydration cementitious peaks, and overall thermal behaviour of the developed binder systems). The outcomes of this study were intended to provide further insight into the hydration kinetics of using MgO wastes and GGBS as an activator and precursor, respectively, in relation to binder optimization and improve on the sustainability impacts of applying this thermo-chemical approach. However, optimization as related to the chemical and thermal performance of the binder systems was only considered in the current study.

\section{Materials and Methodology}

\subsection{Materials}

Characterisation of materials employed in research is a key parameter of understanding the composition/structure of the investigated material and potential performance within a system developed prior to any optimization process. The materials used for this research were Portland cement-PC (CEM 1-42.5N), magnesium oxide wastes (MgO), 
ground granulated blast-furnace slag (GGBS), and de-ionized water. PC was manufactured in compliance with BS EN 197-1 [23] and supplied by Lafarge Cement UK. GGBS as a latent hydraulic material was supplied and used in accordance with BS EN 15,167-1 [24] by Civil and Marine Ltd., Llanwern, Newport, UK. The $\mathrm{MgO}$ specimens are waste products obtained as by-products from the mining activities of magnesite $\left(\mathrm{MgCO}_{3}\right)$ by Magnesitas Navarras, Navarra, Spain. There are four (4) different types of $\mathrm{MgO}$ wastes, which are identified as MG1, MG2, MG3, and MG4 in the current study. XRD (X-ray diffraction) analysis was carried out on the raw binder samples under room temperature using a STOE Powder Diffraction System with operating conditions of $\mathrm{CuK} \alpha$ sealed tube. This was operated at a radiation of $1.54060 \mathrm{~nm}$ with a measurement range from 10 to $802 \theta(0)$ at 0.0150 step in compliance with ASTM C1365-18 [21]. A qualitative phase analysis (QPA) was further carried out on the XRD patterns using a Match3! Analysis software to identify the crystalline cement phases [22].

Tables 1 and 2 and Figure 1 shows the chemical composition, properties, and XRD plots for all the binder materials (CEM I, MG1, MG2, MG3, MG4, and GGBS). Some of the main identified crystalline phases are periclase $(\mathrm{MgO})$ at $42.9,62.3,75.1$, and $78.920(0)$, lime $(\mathrm{CaO})$, quartz $\left(\mathrm{SiO}_{2}\right)$, anhydrite $\left(\mathrm{CaSO}_{4}\right)$, and alite $\left(3 \mathrm{CaO} \cdot \mathrm{SiO}_{2}\right)$. It was observed that calcium oxide $(\mathrm{CaO})$, silicon dioxide $\left(\mathrm{SiO}_{2}\right)$, magnesium oxide $(\mathrm{MgO})$, and sulphur trioxide $\left(\mathrm{SO}_{3}\right)$ are the dominant elements within the compositions of the identified magnesium oxide wastes. This was further substantiated by the XRD patterns indicating the crystallized forms (minor clinker and cement phases) of the identified elements as periclase $(\mathrm{MgO})$ at $42.9,62.3,75.1$, and $78.920(0)$, lime $(\mathrm{CaO})$, quartz $\left(\mathrm{SiO}_{2}\right)$, gypsum $\left(\right.$ Anhydrite $\left.-\mathrm{CaSO}{ }_{4}\right)$, and alite $\left(3 \mathrm{CaO} \cdot \mathrm{SiO}_{2}\right)$.

Table 1. Chemical composition of blended materials.

\begin{tabular}{ccccccc}
\hline & \multicolumn{5}{c}{ Composition (wt.\%) } \\
\cline { 2 - 6 } Oxide & CEM I & MG1 & MG2 & MG3 & MG4 & GGBS \\
\hline $\mathrm{CaO}$ & 61.49 & 9.39 & 3.28 & 6.02 & 32.41 & 37.99 \\
$\mathrm{SiO}$ & 18.84 & 2.51 & 3.33 & 4.90 & 1.20 & 35.54 \\
$\mathrm{Al}_{2} \mathrm{O}_{3}$ & 4.77 & 0.52 & 0.83 & 1.09 & 0.52 & 11.46 \\
$\mathrm{MgO}$ & 3.54 & 56.26 & 78.44 & 45.61 & 24.79 & 8.78 \\
$\mathrm{Fe}_{2} \mathrm{O}_{3}$ & 2.87 & 2.13 & 2.82 & 2.43 & 1.05 & 0.42 \\
$\mathrm{Mn}_{2} \mathrm{O}_{3}$ & 0.05 & 0.15 & 0.27 & 0.16 & 0.08 & 0.43 \\
$\mathrm{SO}_{3}$ & 3.12 & 6.22 & 0.30 & 1.85 & 17.83 & 1.54 \\
$\mathrm{TiO}_{2}$ & 0.26 & 0.01 & $<0.01$ & 0.04 & $<0.01$ & 0.70 \\
$\mathrm{~K}_{2} \mathrm{O}$ & 0.57 & 0.18 & 0.10 & 0.10 & 0.23 & 0.43 \\
$\mathrm{Na}_{2} \mathrm{O}$ & 0.02 & 0.09 & 0.03 & 0.06 & 0.13 & 0.37 \\
$\mathrm{P}_{2} \mathrm{O}_{5}$ & 0.10 & 0.06 & 0.06 & 0.06 & 0.05 & 0.02 \\
$\mathrm{~V}_{2} \mathrm{O}_{5}$ & 0.06 & 0.10 & $<0.01$ & 0.10 & 0.07 & 0.04 \\
$\mathrm{BaO}$ & 0.05 & 0.01 & $<0.01$ & 0.01 & $<0.01$ & 0.09 \\
L.O.I & 4.30 & 22.30 & 10.70 & 37.40 & 21.80 & 2.00 \\
\hline
\end{tabular}


Table 2. Properties of blended materials.

\begin{tabular}{|c|c|c|c|c|c|c|}
\hline \multirow{2}{*}{ Properties } & \multicolumn{6}{|c|}{ Binders } \\
\hline & CEM 1 & MG1 & MG2 & MG3 & MG4 & GGBS \\
\hline \multicolumn{7}{|l|}{ Particle diameter } \\
\hline $\begin{array}{l}\text { Median } \mathrm{d}_{50}(\mu \mathrm{m}) \\
\text { Physical properties }\end{array}$ & 18.86 & 16.24 & 18.72 & 62.74 & 6.52 & 13.69 \\
\hline Colour & Grey & Light-Brown & Very pale brown & Greyish brown & Pale brown & Off-white \\
\hline Bulk density $\left(\mathrm{kg} / \mathrm{m}^{3}\right)$ & - & - & - & - & - & 1200 \\
\hline $\begin{array}{c}\text { Particle density } / \text { Specific } \\
\text { gravity }\left(\mathrm{Mg} / \mathrm{m}^{3}\right) \\
\text { Others }\end{array}$ & 3.16 & 2.86 & 2.91 & 2.88 & 2.65 & 2.90 \\
\hline $\mathrm{pH}$ value & 12.86 & 10.79 & 12.04 & 11.09 & 12.95 & 10.20 \\
\hline Reactivity (m) & - & 30 & 1.8 & $>1440$ & $>1440$ & - \\
\hline
\end{tabular}

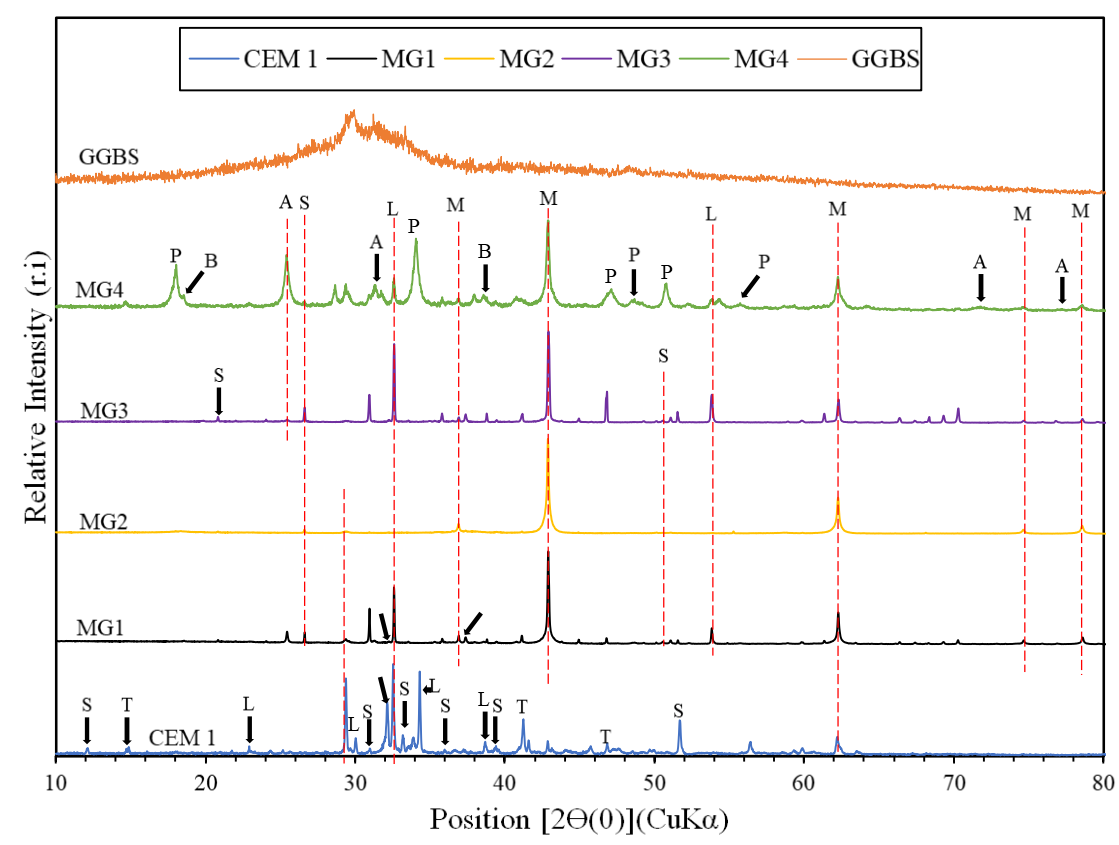

Periclase $(\mathrm{MgO})-\mathrm{M}$, Lime $(\mathrm{CaO})-\mathrm{L}$, Quartz $\left(\mathrm{SiO}_{2}\right)-\mathrm{S}$, Portlandite $\left(\mathrm{Ca}(\mathrm{OH})_{2}\right)-\mathrm{P}$, Gypsum (Anhydrite $\left.-\mathrm{CaSO}_{4}\right)-\mathrm{A}$, Alite $\left(3 \mathrm{CaO} \cdot \mathrm{SiO}_{2}\right)-\mathrm{T}$.

Figure 1. XRD plots for binder materials.

The XRD patterns for GGBS indicated a rather glassy phase, while the particle size distribution shown in Figure 2 was performed using a Malvern Mastersizer 2000 equipment in accordance with BS EN ISO 17,892-4 [25], and it indicated that the $\mathrm{d}_{50}$ values for MG1, MG2, MG3, and MG4 as 16.24, 18.72, 62.74, and $6.52 \mu \mathrm{m}$, respectively. This shows that MG4 was the finest material, while MG3 was the least fine material among the four types of binders. Additionally, the reactivity values as shown in Table 2 indicate the level of reactivity for each $\mathrm{MgO}$ waste material. However, it should be noted that smaller values indicate high reactivity [26]. Therefore, in the order of reactivity, MG1 is more reactive than others while MG3 is the least reactive. 


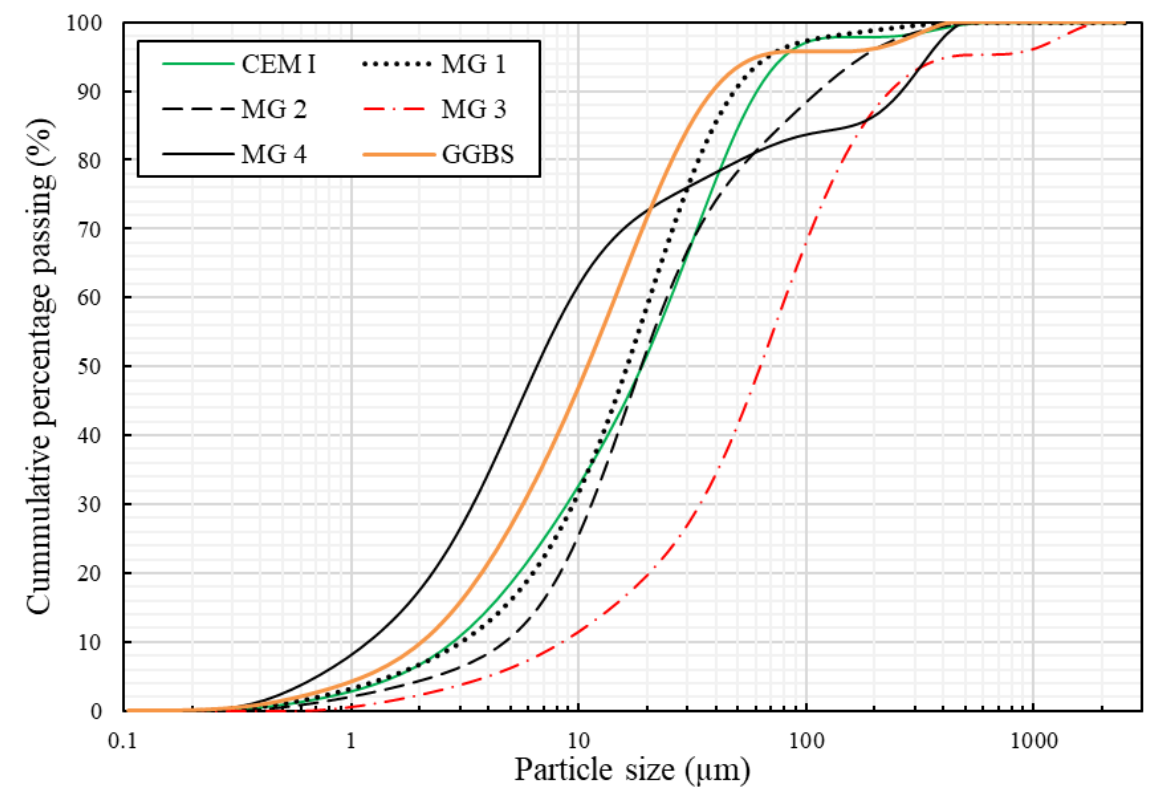

Figure 2. Particle size distribution curves for CEM I, MG1, MG2, MG3, and MG4 and GGBS.

\subsection{Mix Design and Sample Preparation}

The dry MgO-waste-GGBS mixtures were designed with the mind-set of using $\mathrm{MgO}$ as a waste material (blend mixtures with a large amount of $\mathrm{MgO}$-waste) to activate lower proportions of GGBS. This was found to be necessary due to the current trend of using $\mathrm{MgO}$ as an activator $[2,3,5,27,28]$, instead of exploiting the overall expected sustainability potential and impact of using $\mathrm{MgO}$ in large quantities as a waste material within a mix design. Table 3 shows the mix design for seventeen (17) blend compositions for the dry sample mixtures. They were produced by using three (3) levels of $\mathrm{MgO}$-waste proportions by weight $(90,80$, and $70 \mathrm{wt} . \%)$ with GGBS to produce groups of four blend systems (MG1, MG2, MG3, and MG4), while the control mix was composed of $100 \mathrm{wt} . \% \mathrm{CEM} \mathrm{I.} \mathrm{The} \mathrm{dry}$ powders of $\mathrm{MgO}$-waste with GGBS were measured to the predetermined quantities, placed in a mechanical mixer, and thoroughly mixed for $10 \mathrm{~min}$. This was done to ensure the homogeneity of the mixtures, as it was established that the attainment of homogeneity for dry binder samples could be problematic due to the inherent lower shear force between the fine particles, even with increased blending time [20]. Additionally, ceramic balls were placed in the mechanical mixer to further improve on the homogeneity of the mixes. Afterwards, the blended mixes were stored in well-labelled flat tins and placed in a desiccator after the completion of the mixing regime. Figure 3 shows the schematic layout of the experimental mix design. 
Table 3. Experimental mix blends showing anhydrous blend mixes.

\begin{tabular}{|c|c|c|c|c|c|c|c|}
\hline \multirow{2}{*}{ Mix System } & \multirow{2}{*}{ Blend Composition } & \multicolumn{6}{|c|}{ Composition (wt.\%) } \\
\hline & & CEM 1 & MG1 & MG2 & MG3 & MG4 & GGBS \\
\hline $\begin{array}{l}\text { CEM I system } \\
\text { (Control) }\end{array}$ & 100CEM 1:0GGBS & 100 & - & - & - & - & - \\
\hline \multirow{3}{*}{ MG1 System } & 90MG1:10GGBS & - & 90 & - & - & - & 10 \\
\hline & 80MG1:20GGBS & - & 80 & - & - & - & 20 \\
\hline & 70MG1:30GGBS & - & 70 & - & - & - & 30 \\
\hline \multirow{3}{*}{ MG2 system } & 90MG2:10GGBS & - & - & 90 & - & - & 10 \\
\hline & 80MG2:20GGBS & - & - & 80 & - & - & 20 \\
\hline & 70MG2:30GGBS & - & - & 70 & - & - & 30 \\
\hline \multirow{3}{*}{ MG3 system } & 90MG3:10GGBS & - & - & - & 90 & - & 10 \\
\hline & 80MG3:20GGBS & - & - & - & 80 & - & 20 \\
\hline & 70MG3:30GGBS & - & - & - & 70 & - & 30 \\
\hline \multirow{3}{*}{ MG4 system } & 90MG4:10GGBS & - & - & - & - & 90 & 10 \\
\hline & 80MG4:20GGBS & - & - & - & - & 80 & 20 \\
\hline & 70MG4:30GGBS & - & - & - & - & 70 & 30 \\
\hline
\end{tabular}

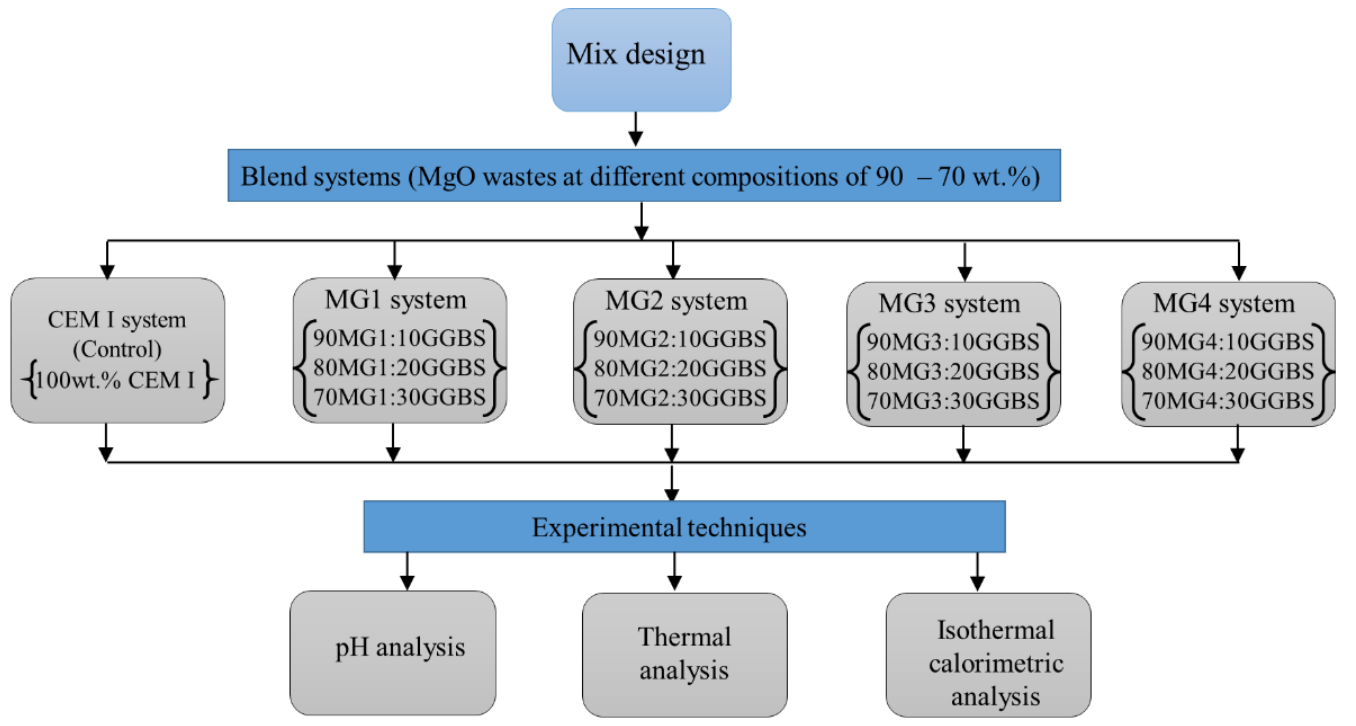

Figure 3. A schematic representation of the experimental mix design.

\subsection{Experimental Techniques}

The $\mathrm{pH}$ values for each binder composition were obtained in accordance with BS EN ISO 787-9 [29] using a Hanna HI-8314 water-resistant hand-held $\mathrm{pH}, \mathrm{mV} /$ Temperature Meter with an HI-1217D pre-amplified $\mathrm{pH}$ electrode/internal temperature sensor at an accuracy of \pm 0.01 . The test was carried out in triplicate and the average value evaluated and recorded. A suspension was developed using five grams ( $5 \mathrm{~g})$ of the designed blend mixtures (Table 3) with $50 \mathrm{~mL}$ of deionized water in a $100 \mathrm{~mL}$ glass beaker and mixed vigorously using a magnetic stirrer. The suspension was allowed to stand for $5 \mathrm{~min}$ to allow the residue to settle. Afterwards, the electrode in the portable $\mathrm{pH} / \mathrm{mV} /{ }^{\circ} \mathrm{C}$ meter was then inserted in the solution and the $\mathrm{pH}$ value obtained. The thermal analysis (thermogravimetric and derivative thermogravimetric analyses (TG/DTG)) was investigated using a Hi-Res TGA55 TA Instrument thermal apparatus for the phases present in the hydration reaction of the blended compositions in compliance with ASTM E2550-17 [30]. The dry sample mixtures were initially placed in a desiccator at a low temperature of $400{ }^{\circ} \mathrm{C}$ containing silica gel for accelerated drying of samples to a constant weight. This was performed to remove any free water and to preserve the hydration products and any other combustible 
phases [31]. The dry sample mixtures were tested in alumina crucibles under an argon gas atmosphere at a heating rate of $100{ }^{\circ} \mathrm{C} / \mathrm{min}$ up to $1000^{\circ} \mathrm{C}$. The weight loss (\%) and derivative weight $\mathrm{d}($ Weight $) / \mathrm{d}(\mathrm{D})\left(\% /{ }^{\circ} \mathrm{C}\right)$ data were logged, collated, and analysed using a TRIOS Thermal Analysis software.

Calorimetric analysis was carried out to investigate the hydration kinetics of the proposed experimental blend mixtures (binders) by directly measuring the rate of heat produced during the hydration process within a thermostated isothermal calorimetry chamber. The heat production rate (thermal power) was determined at a controlled temperature for a period of $72 \mathrm{~h}$ using a ToniCAL Isothermal Calorimeter from Toni Technik, Germany (Figure 4). Five grams (5 g) of the dry sample for the different types of MgO-GGBS compositions were placed in a calorimetry specimen tube [32]. The specimen tube was placed in the calorimetry chamber covered with a lid, and deionized water was introduced using a syringe after equilibrium had been achieved within the thermostated chamber to produce a paste using a $\mathrm{w} / \mathrm{b}$ of 0.5 . The heat produced during the hydration reaction was detected, stored, and analysed using a data acquisition system (ToniDCA Analysis software) in compliance with BS EN 196-11 [33].

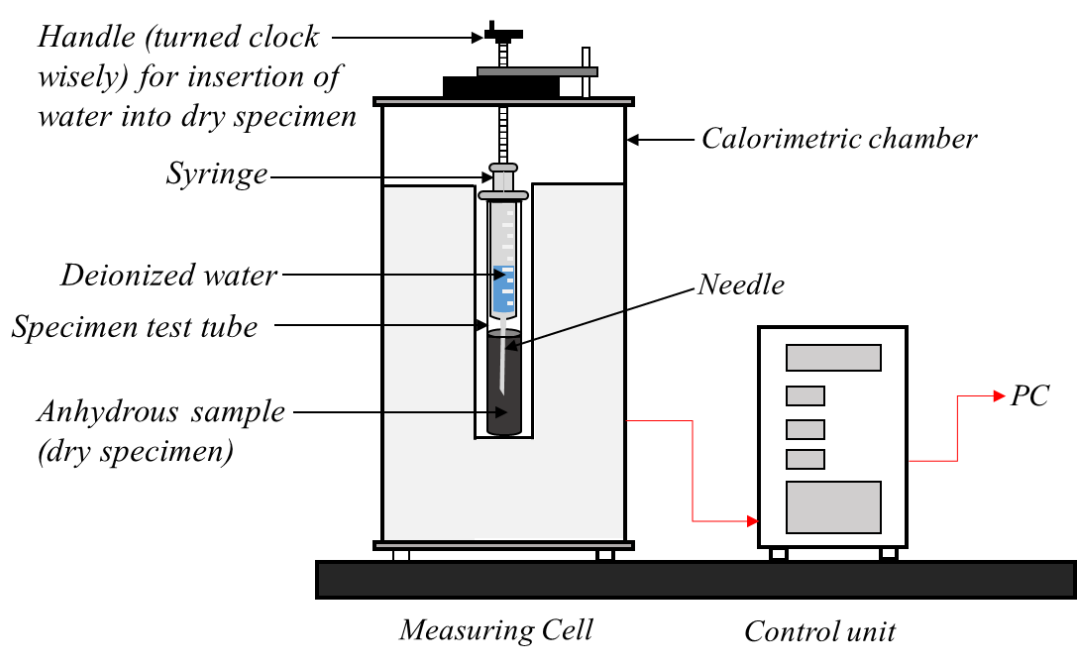

Figure 4. A schematic representation of a ToniCAL Isothermal Calorimeter.

\section{Results}

\section{1. $\mathrm{pH}$ Analysis}

Figure 5 presents an illustration of the $\mathrm{pH}$ levels for the various MgO-waste:GGBS mix compositions that were produced for each binder system. The results show the performance of the $\mathrm{pH}$ levels of binder compositions using three (3) high levels (90, 80, and $70 \mathrm{wt} . \%)$ of MgO wastes (MG1, MG2, MG3, and MG4) with GGBS and 100 wt.\% CEM I (Control). It was observed that the mix compositions within the M4 binder system all produced significant $\mathrm{pH}$ values of 13 (90 wt.\%), 13.1 (80 wt.\%), and 13.1 (70 wt.\%), which are all 5\% lower than that of the control mix (100 wt.\% CEM I) that produced a $\mathrm{pH}$ value of 13.9. An obvious reason for this trend could be due to the combined individual amount of Calcium (Ca) content from MG4 and GGBS present within the blend compositions for MG4 blend systems. However, the MG2, MG3, and MG1 binder systems all produced lower $\mathrm{pH}$ values within the range of 11.1-11.2, which was about $23-25 \%$ lower than that of the control mix. A possible justification for the lower $\mathrm{pH}$ values could be due to the lower combined amount of Ca present within the MgO:GGBS compositions within each binder system (MG2, MG3, and MG1). Generally, the results of the $\mathrm{pH}$ values indicate that all the mix compositions within each binder system are all alkaline (basic) in nature (11-14). 


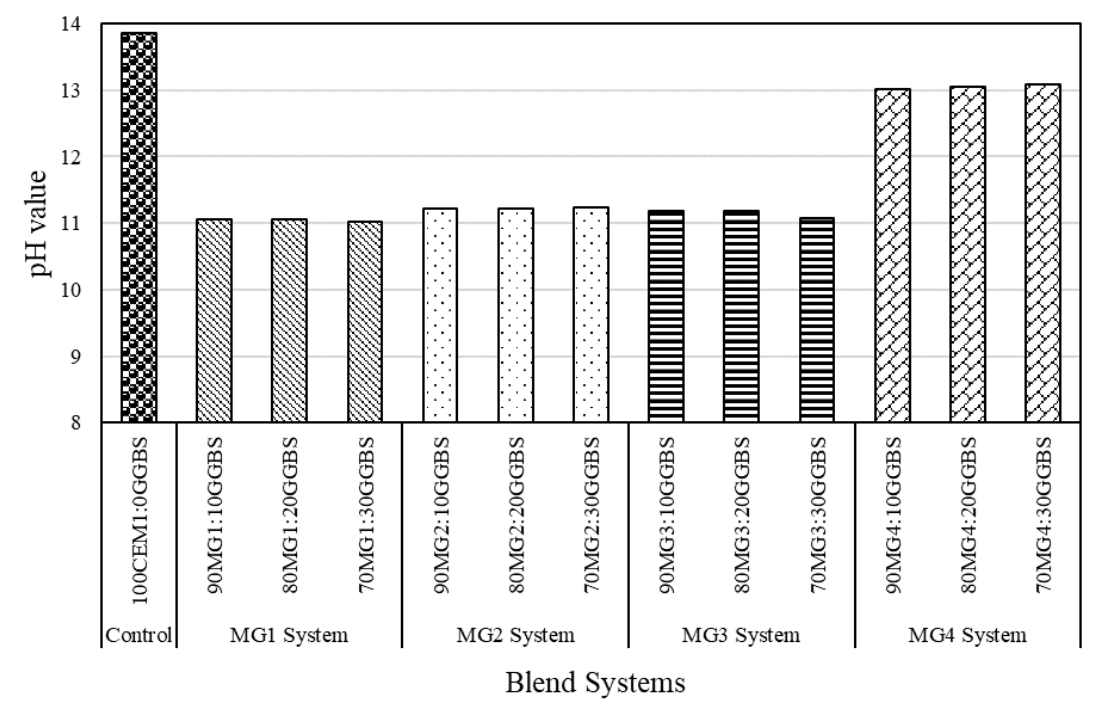

Figure 5. pH summary of mix blend systems.

\subsection{Thermal Analysis}

Figures 6-9 shows the TG/DTG plots for all the blend compositions within each $\mathrm{MgO}$ waste blend system. Generally, $\mathrm{MgO}$ wastes had a large impact on the hydration process as they can be seen to have influenced the pattern of the TG/DTG curves that were produced for all the blended mixtures compared with GGBS.

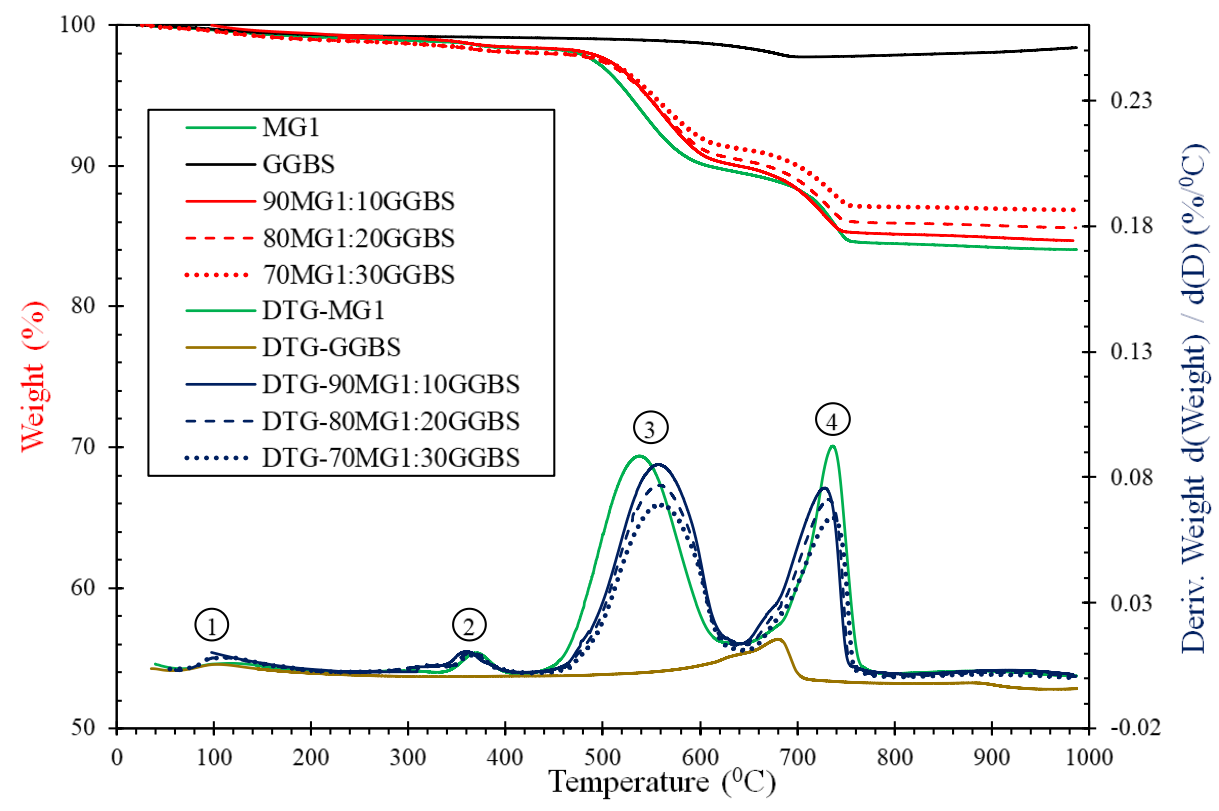

Figure 6. TG and DTG analysis results for blended mixtures with MG2 waste. 


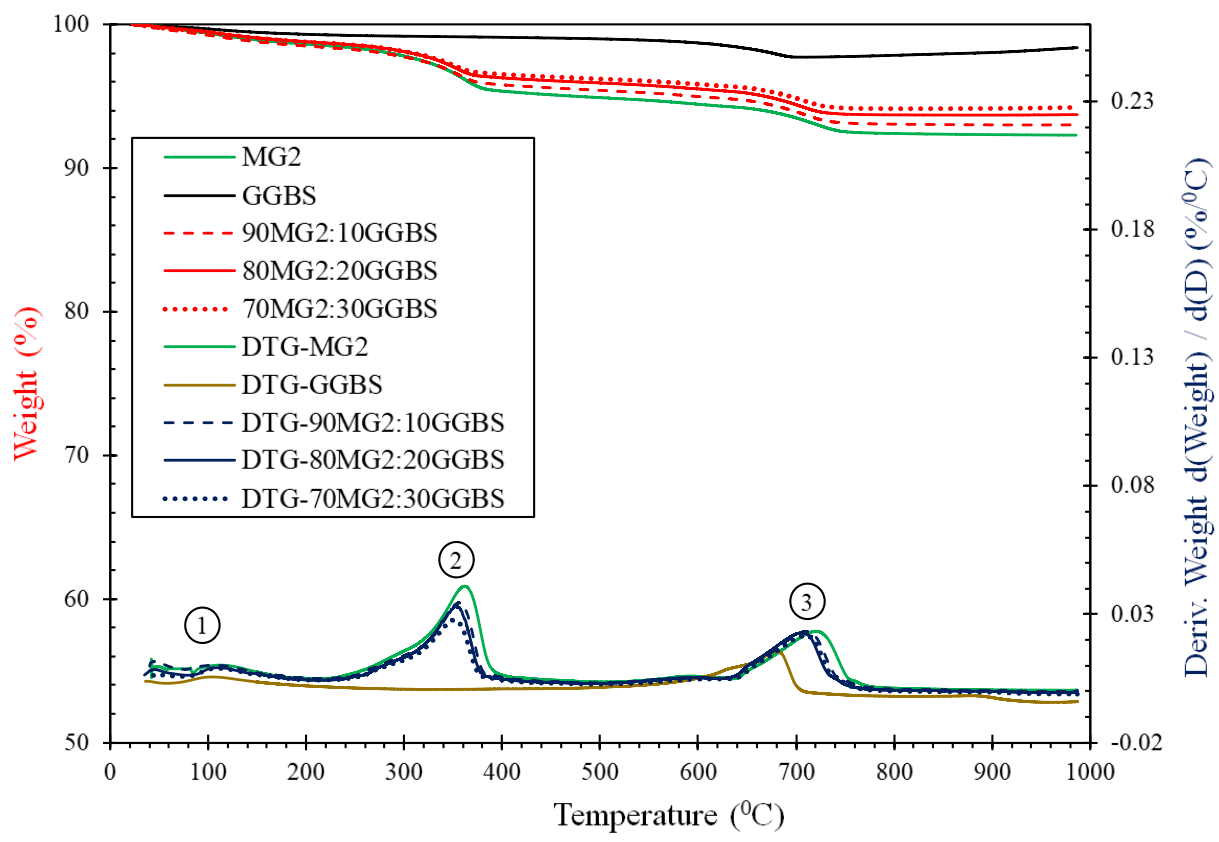

Figure 7. TG and DTG analysis results for blended mixtures with MG2 waste.

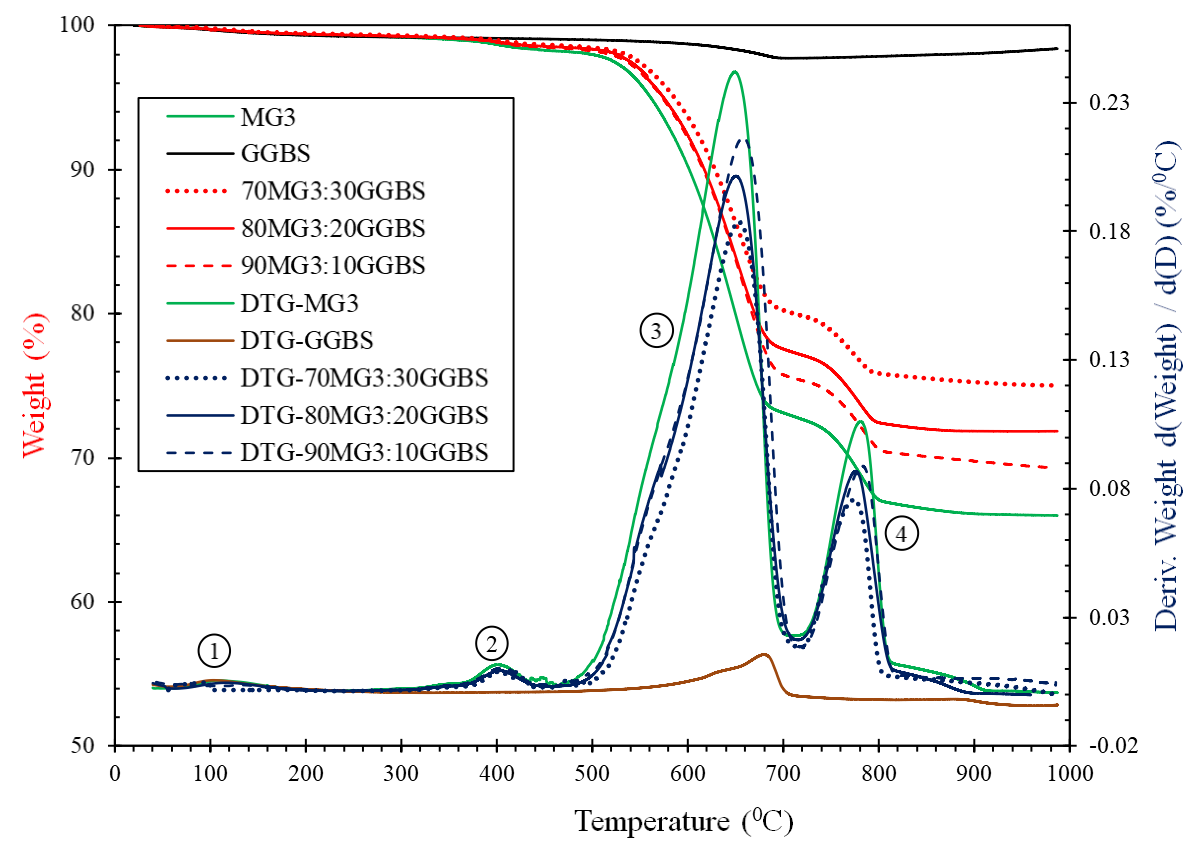

Figure 8. TG and DTG analysis results for blended mixtures with MG3 waste. 


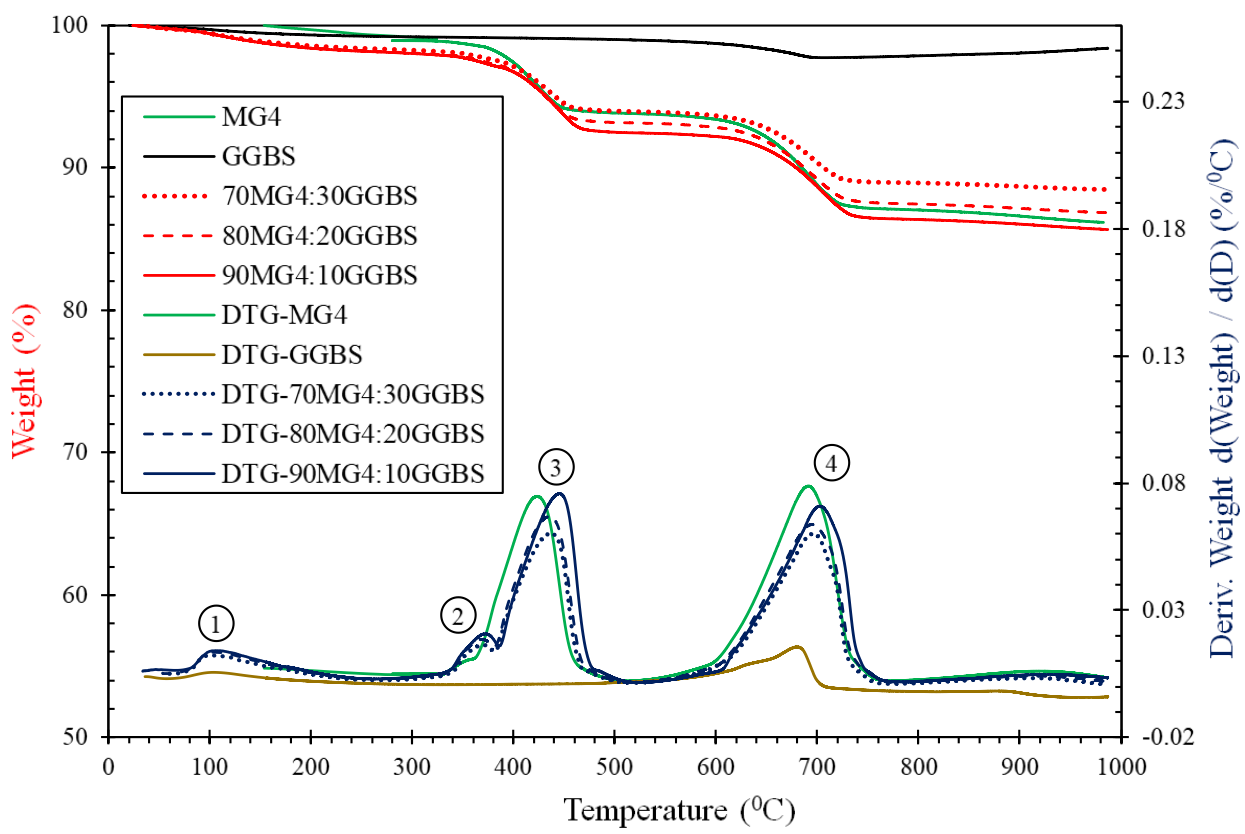

Figure 9. TG and DTG analysis results for blended mixtures with MG4 waste.

Four main endothermic peaks are evident at location points 1, 2, 3, and 4 for blend systems MG1, MG3, and MG4 with corresponding weight losses at varying temperature ranges. However, blend compositions in the MG2 blend system only achieved three endothermic peaks. The position of each endothermic peak depends mainly on the type of structure and the binding of the hydroxyls of the $\mathrm{MgO}$ wastes and GGBS, whereas their (endothermic peaks) shape and range depend more on the crystallinity or particle size distribution of the $\mathrm{MgO}$ wastes and GGBS [34]. The highest peak intensities were developed by MG3 type of $\mathrm{MgO}$ waste material at every location (1, 2, 3, and 4) followed by MG1, MG4, and MG2, respectively. This trend of peak intensity heights was also concurrent with the blend compositions $(90,80$, and $70 \mathrm{wt} . \% \mathrm{MgO}$ content) produced by the $\mathrm{MgO}$ wastes as they could have been largely influenced by the $\mathrm{MgO}$ waste material in each composition. It was also evident that all the blend compositions in each blend system exhibited the same pattern as the individual $\mathrm{MgO}$ material waste. This suggests that the $\mathrm{MgO}$ material had a major influence on the performance of the developing MgO:GGBS binder. However, this was not the case for the individual GGBS as it exhibited only an endothermic peak at $680^{\circ} \mathrm{C}$, which is the lowest peak intensity. For the MgO:GGBS systems, all the blend compositions with $90 \mathrm{wt} . \% \mathrm{MgO}$ content produced the highest endothermic peak intensity for all the blend systems. Moreover, there was a gradual reduction in endothermic peak intensities for every gradual reduction in the quantity of $\mathrm{MgO}$ waste (90, 80, and $70 \mathrm{wt} . \%$ ) in each blend system (MG1, MG2, MG3, and MG4).

Figure 10 shows the summary of total weight losses after the complete thermal analysis of all the blend compositions for each $\mathrm{MgO}$ waste blend system, which were obtained from the TG/DTG plots in Figures 6-9. This is one of the optimization design criteria for choosing the best performing binder system. The largest weight loss was experienced by MG3 blend system with 90, 80, and $70 \mathrm{wt} . \% \mathrm{MgO}$ content within the range of $24-31 \%$ while the lowest weight loss was experienced by the control (3.2\%). However, blend compositions within the MG2 blend system produced the lowest weight losses within the range of 6-7\%. With respect to each individual binder material (MG1, MG2, MG3, MG4, and GGBS), Figures 6-9 shows that only GGBS was considerably stable (1.6\%), while other material components experienced a significant individual weight loss of 7.7\% (MG2), 13.8\% (MG4), 20\% (MG1), and 34\% (MG3), respectively. 


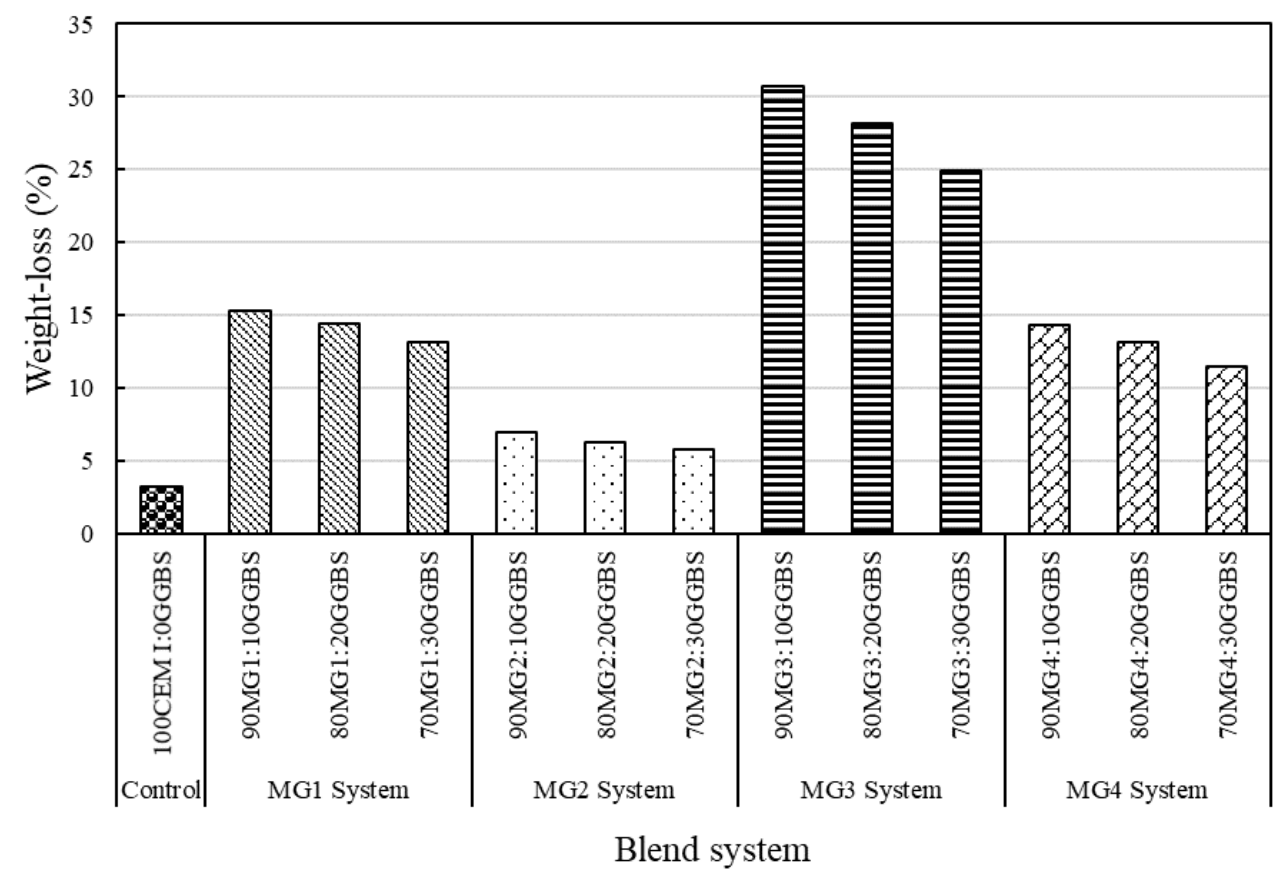

Figure 10. Weight loss (\%) due to thermal analysis for blended mixtures.

\subsection{Isothermal Calorimetric Analysis}

Figures 11 and 12 show a summary of the evolution of the first and second thermal peaks that were obtained from the calorimetric plots in Figures 13-16 for the various hydrated blend systems after $72 \mathrm{~h}$ at $25^{\circ} \mathrm{C}$. A significant evolution of thermal powers was evident in the first peak (18-184 J/gh) for all the investigated blend systems in comparison with thermal powers produced in the second peak (0-32 J/gh). The blend compositions within the MG4 blend system produced the largest intensity of first thermal powers within the range of 153-184 J/gh, while those from MG3 blend systems produced the lowest first thermal powers within the range of $18.2-21.8 \mathrm{~J} / \mathrm{gh}$. Another obvious observation was the gradual reduction in the production of thermal power for every percentage reduction in in the quantity of $\mathrm{MgO}$ content $(90,80$, and $70 \mathrm{wt} . \%)$ for all the $\mathrm{MgO}$ waste materials (MG1, MG2, MG3, and MG4). The magnitude of thermal powers that were produced in the second peaks within the MG1 systems, were significantly higher and about $48-60 \%$ higher than the Control. The reverse was the case for the mix compositions produced from other blend systems (MG2, MG3, and MG4 systems), as their thermal powers were considerably lower $(0-56 \%)$ than the control. 


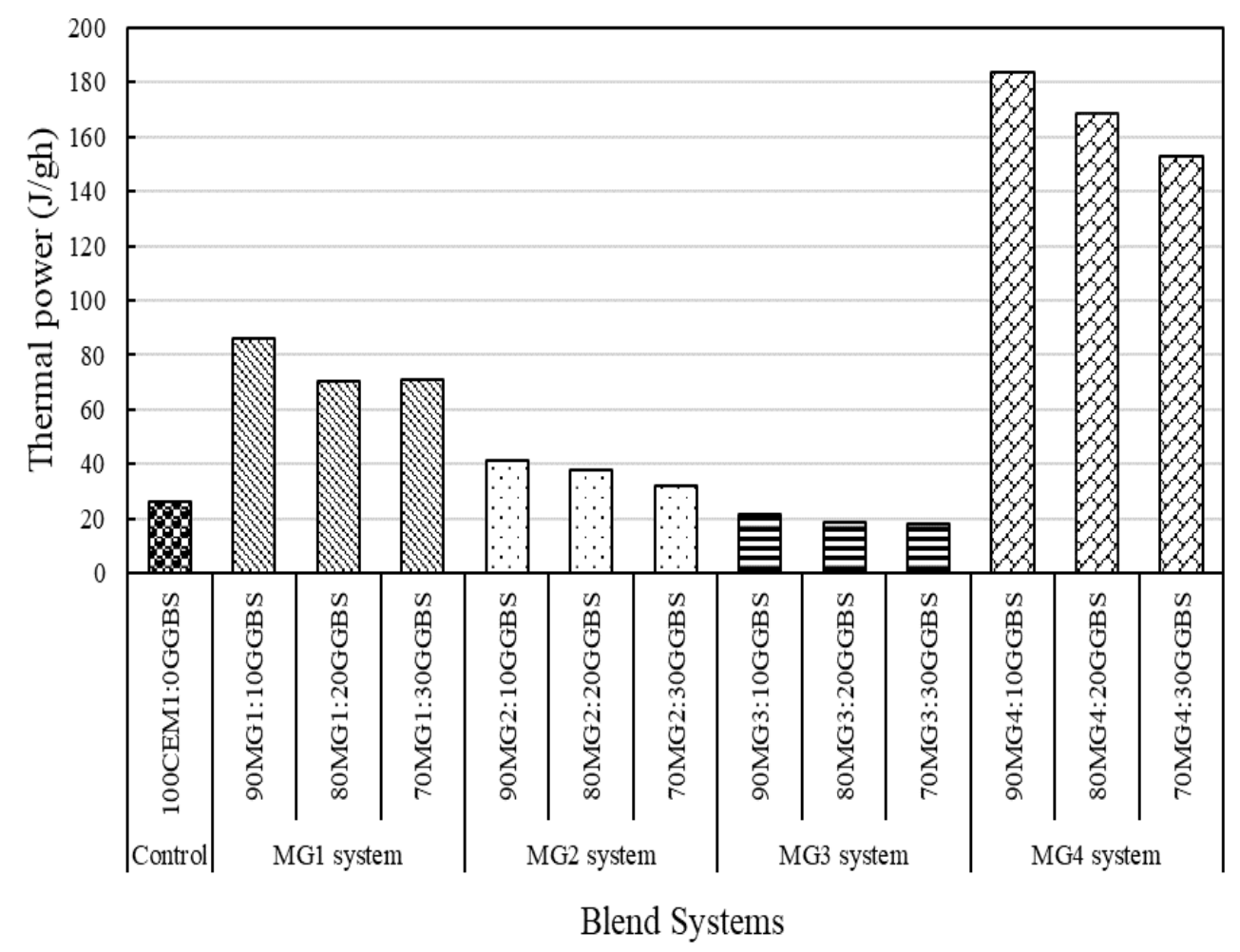

Figure 11. Calorimetric 1st thermal power for hydrated blended mixtures after $72 \mathrm{~h}$ at $25^{\circ} \mathrm{C}$.

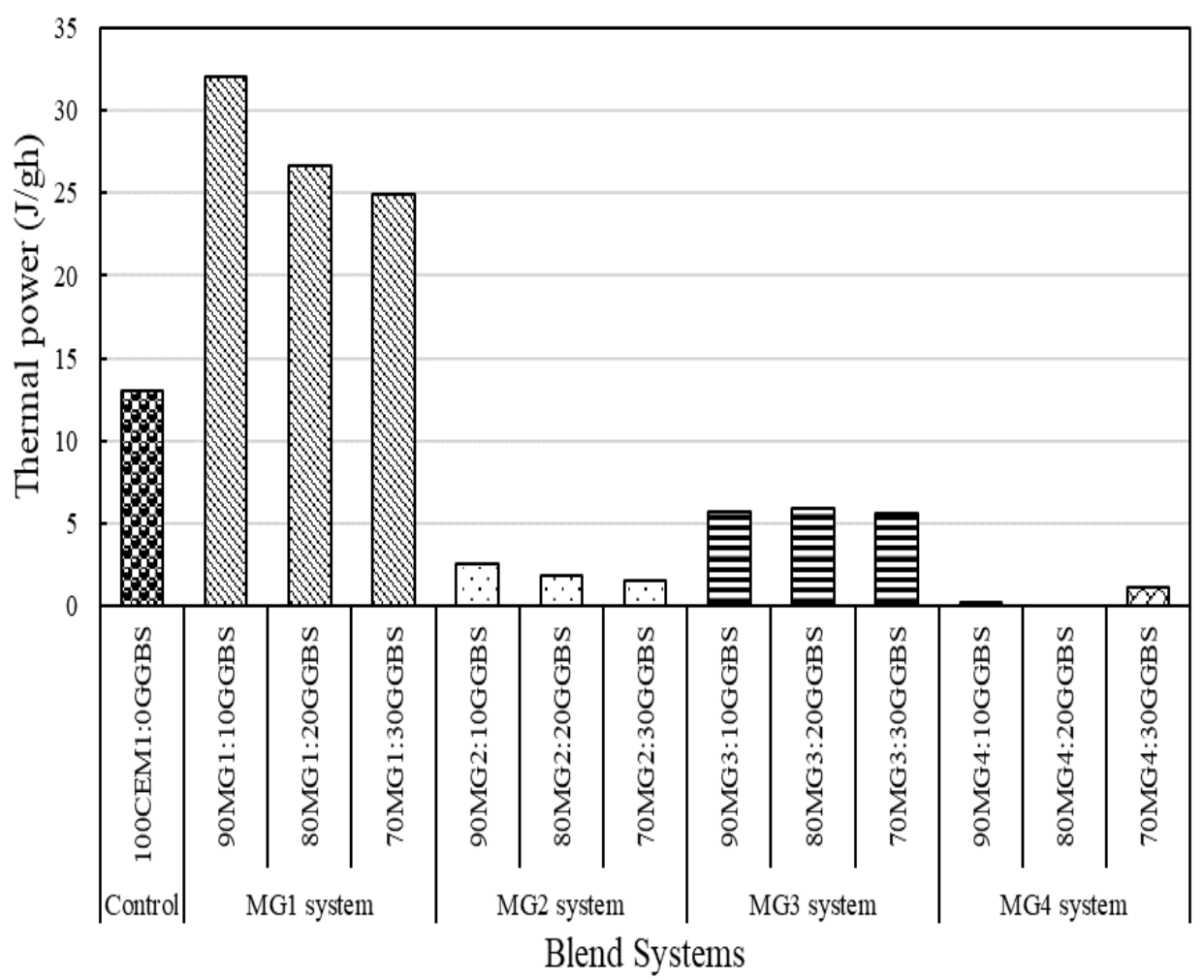

Figure 12. Calorimetric 2 nd thermal power for hydrated blended mixtures after $72 \mathrm{~h}$ at $25^{\circ} \mathrm{C}$. 


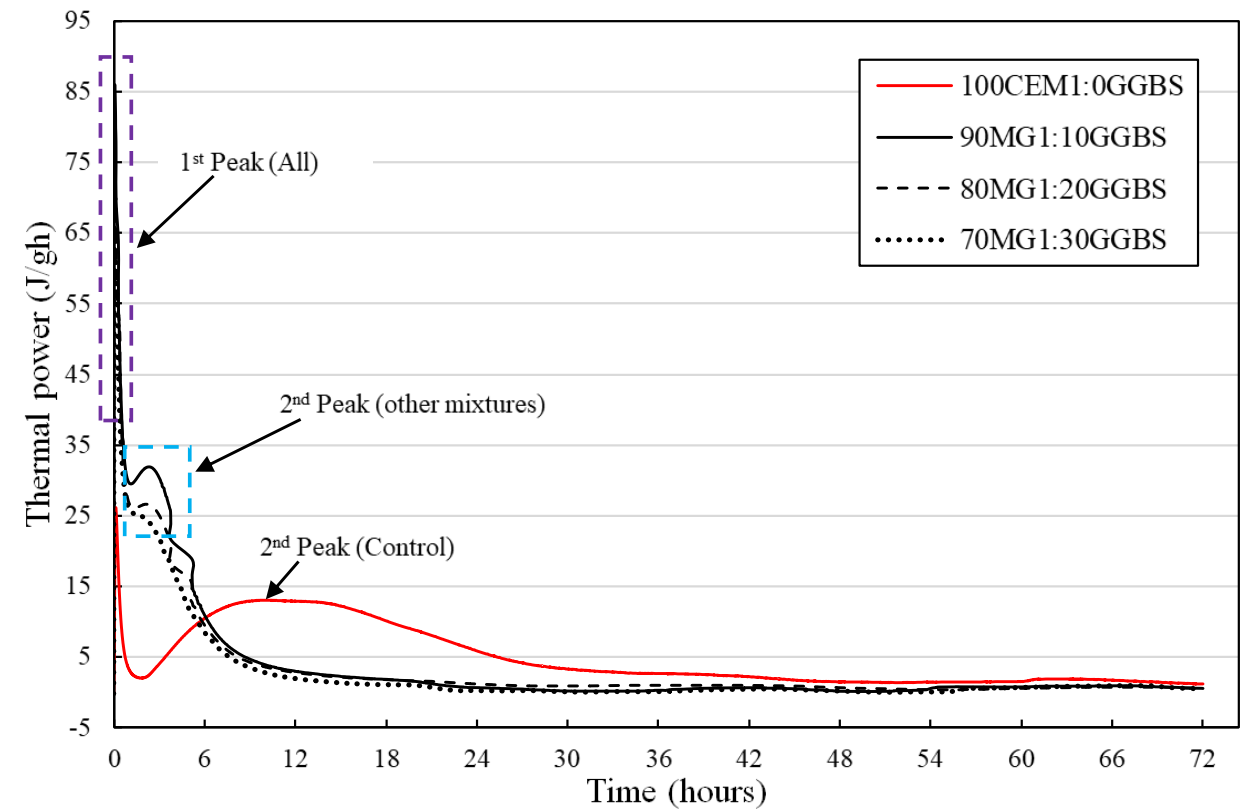

Figure 13. Calorimetric curves for blended mixtures in MG1 blend system after hydration at $25^{\circ} \mathrm{C}$.

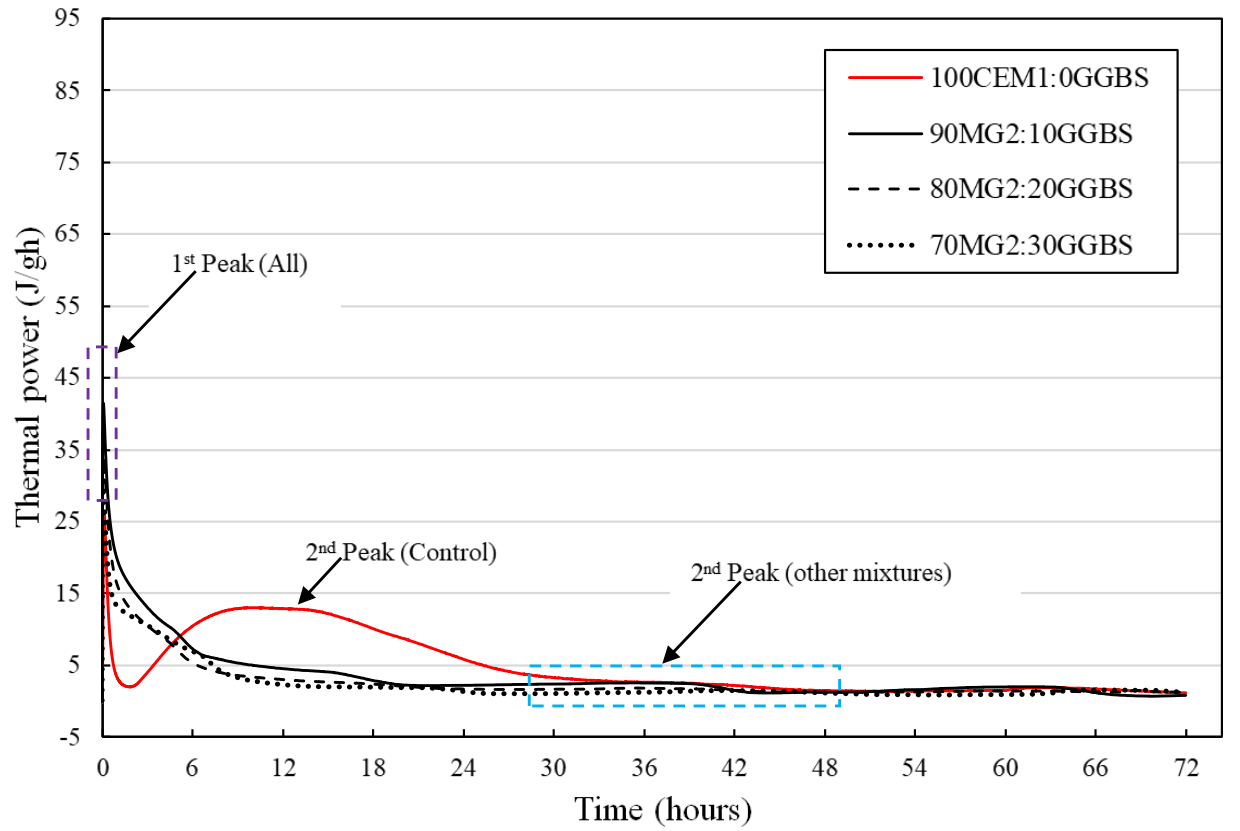

Figure 14. Calorimetric curves for blended mixtures in MG2 blend system after hydration at $25^{\circ} \mathrm{C}$. 


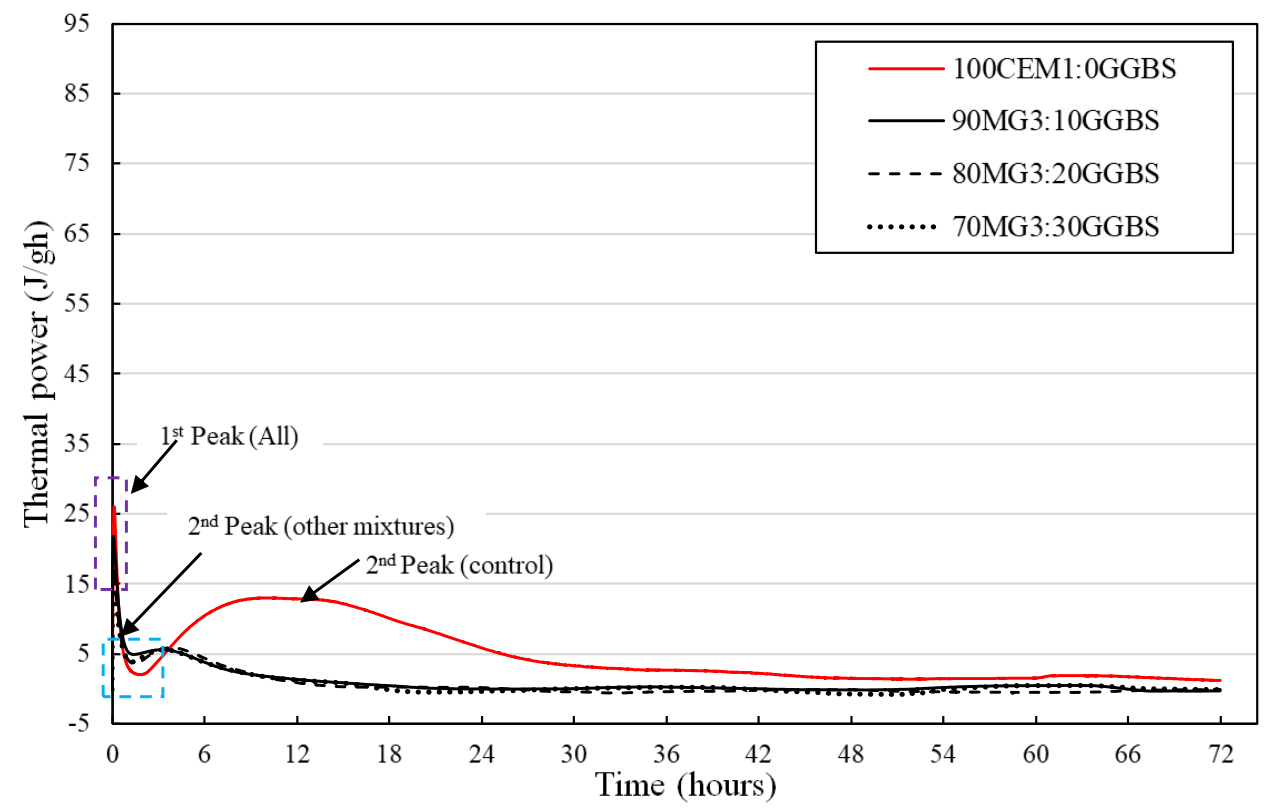

Figure 15. Calorimetric curves for blended mixtures in MG3 blend system after hydration at $25^{\circ} \mathrm{C}$.

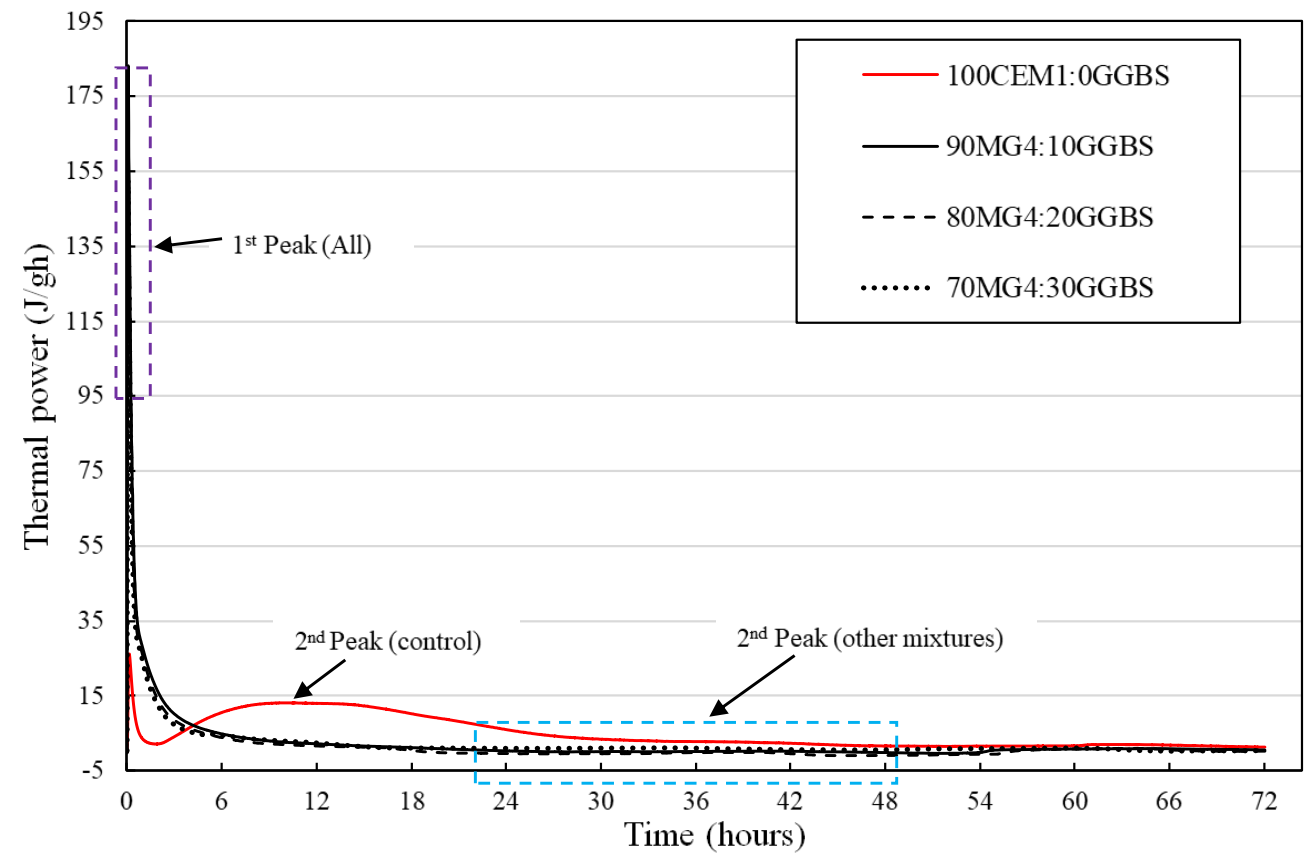

Figure 16. Calorimetric curves for blended mixtures in MG4 blend system after hydration at $25^{\circ} \mathrm{C}$.

Figure 17 shows the calorimetric heat of hydration $(\mathrm{HOH})$ peaks for the hydrated mix compositions, which were obtained from the calorimetric plots in Figure 18. Regarding the blend systems, the mix compositions that were produced from the MG1 systems produced the largest magnitude of $\mathrm{HOH}$ within the range of $191.2-255.3 \mathrm{~J} / \mathrm{g}$, while MG3 systems produced the lowest $\mathrm{HOH}$ of $42.1-64.6 \mathrm{~J} / \mathrm{g}$. A continuous trend of an increase in the production of calorimetric $\mathrm{HOH}$ was evident for all the hydrated mix blends. Although the control mix composition (100 wt.\% CEM I) produced the maximum $\mathrm{HOH}$ value of $339.5 \mathrm{~J} / \mathrm{g}$, all other blend systems (MG1, MG2, MG3, and MG3) showed potential for more production of $\mathrm{HOH}$. 


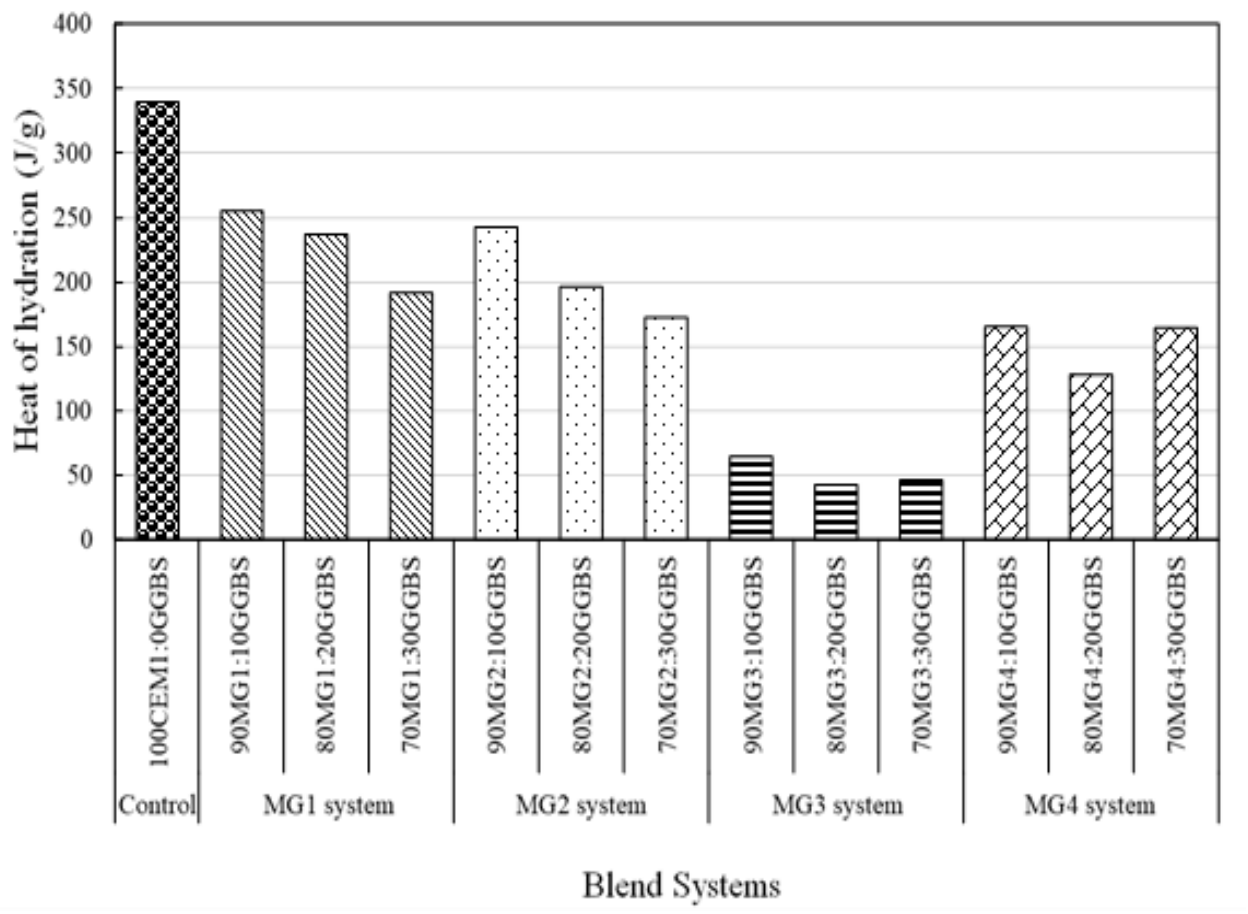

Figure 17. Calorimetric heat of hydration peaks for hydrated blended mixtures after $72 \mathrm{~h}$ at $25^{\circ} \mathrm{C}$.

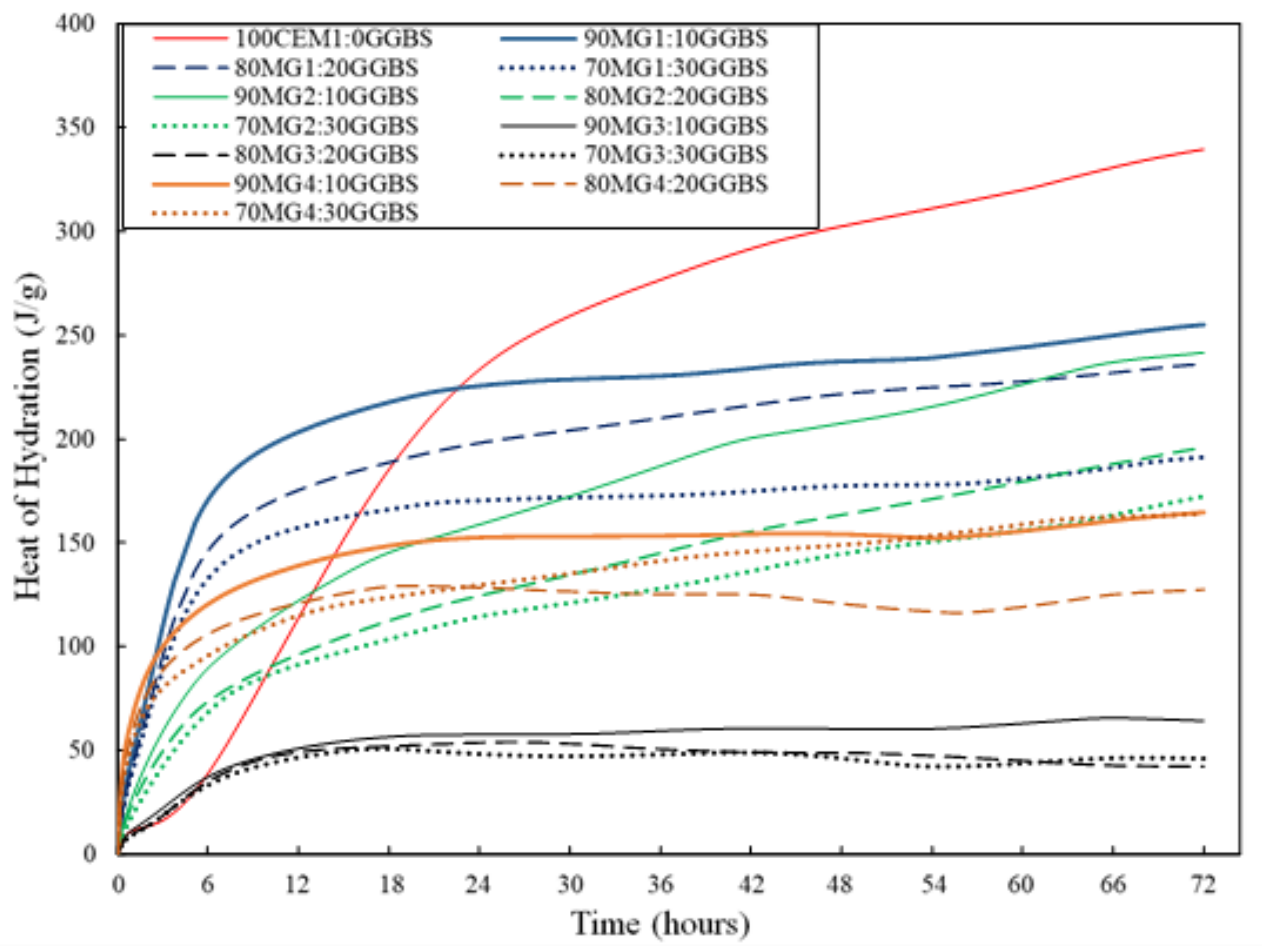

Figure 18. Calorimetric heat of hydration curves for hydrated blended mixtures after $72 \mathrm{~h}$ at $25^{\circ} \mathrm{C}$.

\section{Discussion}

\section{1. $\mathrm{pH}$ Investigation}

$\mathrm{pH}$ or "potential for hydrogen" analysis is a vital parameter used within soil science to properly characterise and understand the activation levels of binder materials. It utilizes a quantitative analysis to measure the acidity or basicity/alkalinity of aqueous solutions, which essentially translates to the inherent amount of hydrogen ion/activity. The observed variation in $\mathrm{pH}$ for the blend compositions in MG1 blend system could be due to the low 
$\mathrm{pH}$ value of the individual MG1 waste materials, which influenced the overall $\mathrm{pH}$ value of each MgO:GGBS blend composition. The trend observed for MG2 and MG4 blend systems of no significant change in $\mathrm{pH}$ value could be attributed to the high individual $\mathrm{pH}$ for MG2 (12.04) and MG4 (12.95) compared with GGBS (10.20), which is suggested to have largely influenced the combined $\mathrm{pH}$ of each $\mathrm{MgO}$ GGBS blend. Generally, the reduced $\mathrm{pH}$ value for the $\mathrm{MgO}$ waste blend systems shows a positive impact of its application as it could lead to low solubility of heavy metals within the waste materials ( $\mathrm{MgO}$ wastes), which eliminates contamination of the environment through leaching of the cementitious binders within a stabilised product [35].

Generally, the low-pH values that were established for the MgO wastes (MG1, MG2, MG3, and MG4) compared with the control give an indication of a good binder/alkaline earth metals in acting as an activator to industrial by-products (GGBS). The alkalinity levels raised the $\mathrm{pH}$ of the initial hydration reaction, which is required to break the silicon dioxide bonds and facilitate a reaction to form a condensed structure [36]. In addition, this is a good attribute (low $\mathrm{pH}$ ) for a binder system, to easily flocculate cations within the interlayer of a clay structure and improved overall binder-clay compatibility [37].

\subsection{Thermal Investigation}

The thermal performance of cement and cementitious systems is a key requirement for understanding their behaviour after undergoing a TG/DTG analysis, which primarily measures the change in weight (individual and total weight loss), identifies various hydration phases (endothermic peaks), and provides an indication to the thermal stability (dehydroxylation, decarbonation, dehydration, decomposition, melting of phase transition) of the investigated blend compositions [20]. A summary of the identified cementitious phases in the investigated un-hydrated $\mathrm{MgO}$ blend systems are shown in Table 4 . This was based on the decomposition of the expected crystalline/amorphous hydration phases from the existing literature. Generally, the observed weight losses between temperature peaks of 0 and $600{ }^{\circ} \mathrm{C}$ are attributed to water loss, while those above $600{ }^{\circ} \mathrm{C}$ are primarily associated with the release of carbon dioxide or decarboxylation [20]. The cementitious phases at varying peak points (temperature) are suggested as brucite, gypsum (dihydrate and anhydrite phase), magnesium silicate hydrate (M-S-H) gel, calcium silicate hydrate (C-S-H) gel, calcium hydroxide, calcium carbonate (calcite), magnesite, and hydrotalcite [20,38,39].

Table 4. Identification and comparison of hydrated cementitious phases for blended mixtures.

\begin{tabular}{|c|c|c|c|c|c|c|c|c|c|c|}
\hline \multirow{3}{*}{$\begin{array}{l}\text { Blend } \\
\text { Systems }\end{array}$} & \multicolumn{10}{|c|}{ Hydrated Cementitious Phases } \\
\hline & \multicolumn{2}{|c|}{ Loose Water $\left(\mathrm{H}_{2} \mathrm{O}\right)$} & \multicolumn{2}{|c|}{$\begin{array}{c}\text { Gypsum } \\
\left(\mathrm{CaSO}_{4} \cdot 2 \mathrm{H}_{2} \mathrm{O}-\mathrm{CaSO}_{4}\right)\end{array}$} & \multicolumn{2}{|c|}{ Brucite $\left(\mathrm{Mg}(\mathrm{OH})_{2}\right)$} & \multicolumn{2}{|c|}{ Magnesite $\left(\mathrm{MgCO}_{3}\right)$} & \multicolumn{2}{|c|}{$\begin{array}{c}\text { Calcium Carbonate } \\
\left(\mathrm{CaCO}_{3}\right)\end{array}$} \\
\hline & $\begin{array}{c}\text { Peak } \\
\text { Location }\end{array}$ & $\begin{array}{l}\text { Temp. } \\
\left({ }^{\circ} \mathrm{C}\right)\end{array}$ & $\begin{array}{c}\text { Peak } \\
\text { Location }\end{array}$ & $\begin{array}{l}\text { Temp. } \\
\left({ }^{\circ} \mathrm{C}\right)\end{array}$ & $\begin{array}{c}\text { Peak } \\
\text { Location }\end{array}$ & $\begin{array}{l}\text { Temp. } \\
\left({ }^{\circ} \mathrm{C}\right)\end{array}$ & $\begin{array}{c}\text { Peak } \\
\text { Location }\end{array}$ & $\begin{array}{l}\text { Temp. } \\
\left({ }^{\circ} \mathrm{C}\right)\end{array}$ & $\begin{array}{c}\text { Peak } \\
\text { Location }\end{array}$ & $\begin{array}{l}\text { Temp. } \\
\left({ }^{\circ} \mathrm{C}\right)\end{array}$ \\
\hline MG1 & 1 & 105 & - & - & 2 & 371 & 3 & 537 & 4 & 737 \\
\hline MG2 & 1 & 103 & - & - & 2 & 360 & - & - & 3 & 709 \\
\hline MG3 & 1 & 101 & - & - & 2 & 401 & 3 & 658 & 4 & 782 \\
\hline MG4 & - & - & 1,2 & $105-371$ & 3 & 446 & - & - & 4 & 703 \\
\hline
\end{tabular}

The endothermic peak points 1 for blend systems MG1, MG2, and MG3 at $101-105^{\circ} \mathrm{C}$ in this study is in line with the findings of Sonat and Unluer [7], who attributed the water loss to the dehydration of loose or poorly bound hydroxyl groups within the element structure. Klein and Hurlbut [40] reported that gypsum is composed of parallel layers of $(\mathrm{SO} 4)^{2+}$ groups in its structure that are strongly bonded to $\left(\mathrm{Ca}^{2+}\right)$ while the parallel layers are bound together by weak water molecules. This explains the decomposition of gypsum at different forms of calcium sulphate dihydrate $\left(\mathrm{CaSO}_{4} \cdot 2 \mathrm{H}_{2} \mathrm{O}\right)$ to calcium sulphate anhydrite $\left(\mathrm{CaSO}_{4}\right)$ between 85 to $400{ }^{\circ} \mathrm{C}[38,39,41]$, which is in line with the observed endothermic peaks at location 1 and 2 for MG4 blend system at 105 to $371{ }^{\circ} \mathrm{C}$. 
The observed peak attributed to the formation of brucite $\left(\mathrm{Mg}(\mathrm{OH})_{2}\right)$ was mainly due to the hydration of magnesium oxide and in the context of thermal analysis, and it occurs when there is the development of a peak within the temperature range of 300 to $450{ }^{\circ} \mathrm{C}$ [7]. Bernard et al. [35] attributed this peak as the dihydroxylation of magnesium hydroxyl groups $(\mathrm{Mg}-\mathrm{OH})$ present within the blend mixtures. The presence of brucite also gives a positive indication of the potential for the formation of cementitious hydrates (M-S-H gel or hydrotalcite) from the investigated alternative binder system [42,43]. With reference to other identified hydrated cementitious phases, calcium carbonate decomposed further at high temperatures between $642-782{ }^{\circ} \mathrm{C}$ for the analysed blended mixtures (Table 4). This is in line with the findings of Song et al. [44] and Collier [39] on the temperature ranges of 650-740, 600-800, and $650-900^{\circ} \mathrm{C}$, respectively, for a complete decomposition of calcium to form calcium carbonate (calcite). This later-stage decomposition can also be attributed to a carbonation effect with respect to the decomposition of calcite present within the blend compositions [45].

The weight loss that was observed is one of the vital parameters for the current binder optimisation process so that the successful binder system will not have a negative impact (shrinkage tendency) on the overall stability of the blend compositions and robustness of the stabilised product that it was applied to. A possible justification for this individual weight loss could be due to the high amount of loss of ignition of carbon compounds for each $\mathrm{MgO}$ waste material (L.O.I from XRF analysis detailing the material oxide compositions in Table 1). In addition, the reduction in the magnitude of endothermic peaks for the blend compositions in each blend system (Figure 10) could be attributed to the increased amount of GGBS content in each mix composition with every gradual reduction in the quantity of $\mathrm{MgO}$ waste $(90,80$, and $70 \mathrm{wt} . \%)$, which possesses stronger crystalline bonds within its molecular structure compared with the binder materials $(\mathrm{MgO})$. Another possible justification could also be attributed to the strength capacity of bonds between the structural layer and hydroxyl group of the hydrated cementitious compound in the blend composition (brucite) $[35,44]$.

\subsection{Isothermal Calorimetric Investigation}

The hydration reaction for hydrated blended mixtures with $\mathrm{MgO}$ can be explained using the simple hydration kinetics reaction, as a function of the generated thermal power $(\mathrm{J} / \mathrm{gh})$ and heat of hydration $(\mathrm{J} / \mathrm{g})$ [18]. Generally, the activation process of GGBS by reactive $\mathrm{MgO}$ begins with an initial destruction of the bonds within the GGBS composition e.g., $\mathrm{Mg}-\mathrm{O}, \mathrm{Ca}-\mathrm{O}, \mathrm{Si}-\mathrm{O}-\mathrm{Si}, \mathrm{Al}-\mathrm{O}-\mathrm{Si}$, and $\mathrm{Al}-\mathrm{O}-\mathrm{Al}$, which is subsequently followed by the development of a $\mathrm{Si}-\mathrm{Al}$ inter-surface layer over the grains of the GGBS material. Thereafter, $\mathrm{Mg}^{2+}$ either reacts with $\mathrm{Si}-\mathrm{O}$ or $\mathrm{Al}-\mathrm{O}$ to produce a cementing hydrate mainly as C-S$\mathrm{H}$ gel and M-S-H gel or hydrotalcite/magnesium aluminate hydrate- $\mathrm{M}-\mathrm{A}-\mathrm{H}[5,15,46]$. Therefore, an overall hydration reaction for a MgO-waste-activated GGBS composition can be summarized in Equation (1).

$$
\begin{aligned}
\mathrm{MgO}+\left(\mathrm{CaO}-\mathrm{MgO}-\mathrm{Al}_{2} \mathrm{O}_{3}-\mathrm{SiO}_{2}\right) \mathrm{GGBS}+\mathrm{H}_{2} \mathrm{O} & \\
& \rightarrow \mathrm{C}-\mathrm{S}-\mathrm{H}+\mathrm{M}-\mathrm{S}-\mathrm{H}+\mathrm{M}-\mathrm{A}-\mathrm{H}(\mathrm{Ht})+\mathrm{C}-\mathrm{A}-\mathrm{S}-\mathrm{H}
\end{aligned}
$$

The rapid increase in thermal production (1st peak) at the initial reaction stages for all the analysed $\mathrm{MgO}$-waste:GGBS blended mixtures can be attributed to the combined exothermic reaction experienced during the hydration of calcium oxide $(\mathrm{CaO})$ and magnesium oxide $(\mathrm{MgO})$ present within their individual composition. This is in line with the research by Amaral et al. [47], who suggested that $\mathrm{Mg}^{2+}$ cations and anions $\left(\mathrm{Cl}^{-}\right.$and $\left.\mathrm{SO}^{2+}\right)$ have an effect on the thermodynamics and kinetics of a hydration reaction. Therefore, the heat that was experienced with respect to $\mathrm{MgO}$-waste blended mixtures results from the hydration of $\mathrm{MgO}$ (Equation (2)), which readily dissolves upon contact with water to mostly form brucite $[48,49]$.

$$
\mathrm{MgO}+\mathrm{H}_{2} \mathrm{O} \rightleftharpoons \mathrm{Mg}(\mathrm{OH})_{2}, \Delta H=-81.02 \mathrm{~kJ} \mathrm{~mol}^{-1}
$$


The extent of thermal power production in the MgO waste:GGBS and CEM I binder systems largely depends on the combined effects of heat production from the $\mathrm{CaO}$ and $\mathrm{MgO}$ with its associated $\mathrm{CaO}$ in the GGBS content. Therefore, the combined presence of $\mathrm{CaO}$ within $\mathrm{MgO}$ :GGBS composition gives rise to the presence of an increased amount of tricalcium aluminate $\left(\mathrm{C}_{3} \mathrm{~A}\right)$, which is responsible for the initial reaction stage [21,50-52]. Some researchers also suggested that the initial sudden thermal power production can also be caused by ettringite formation, due to the hydration reaction that occurs during the complete decomposition of gypsum present within the developed blended mixtures from calcium sulphate hemihydrate $\left(\mathrm{CaSO}_{4} \cdot 1 / 2 \mathrm{H}_{2} \mathrm{O}\right)$ to calcium sulphate dihydrate $\left(\mathrm{CaSO}_{4} \cdot 2 \mathrm{H}_{2} \mathrm{O}\right)$ phase [53]. This phenomenon well explains the high initial thermal peak that was observed for blended mixtures with MG4, which is composed of high levels of sulfur trioxide $\left(\mathrm{SO}_{3}\right)$ in comparison with the control and other $\mathrm{MgO}$ waste materials (see Table 1).

The gradual reduction in the first thermal peaks (thermal power generation) for every percentage increase in replacement levels of PC with $\mathrm{MgO}$ waste materials in all the blend systems could be attributed to the large replacement levels of PC (70, 80, and 90 wt.\%), which is expected to increase the amount of $\mathrm{CaO}$ that is responsible for the initial exothermic reaction resulting in the formation of ettringite, cracks, false strength, and flash setting of the hydrated product [21]. This reduction phenomenon could also be attributed to the reduction in the amount of $\mathrm{MgO}$ present within the blended mixtures. This is in line with the research by Amaral et al. [47] who suggested that $\mathrm{Mg}^{2+}$ cations and anions $\left(\mathrm{Cl}^{-}\right.$ and $\mathrm{SO}^{2+}$ ) have an effect on the thermodynamics and kinetics of a hydration reaction. All the blend mixtures experienced an induction period that is more pronounced in MG1 and MG3 binder systems (Figures 13-16) in which the duration was largely dependent on each material of the blended mixture and binder system. Taylor et al. [54] attributed this occurrence that varies across the blended material as a period of slow hydration reaction with a low production of thermal power, where the protective layer that was developed over the particles of the tricalcium silicate $\left(C_{3} S\right)$ in the initial exothermic/hydration reaction was later destroyed by either phase formation, $\mathrm{pH}$, amount of $\mathrm{Ca}^{2+}$, or ageing (Figure 19). Additionally, the duration of induction period varies across the blended material. It is worth knowing that the occurrence of the second exothermic peaks was mainly due to the further hydration reaction of the released $\mathrm{C}_{3} \mathrm{~S}$ after the initial reaction and induction stage, resulting in the production of more exothermic thermal powers for increased hydration [21]. However, the produced peak and time for complete hydration is material-dependent.

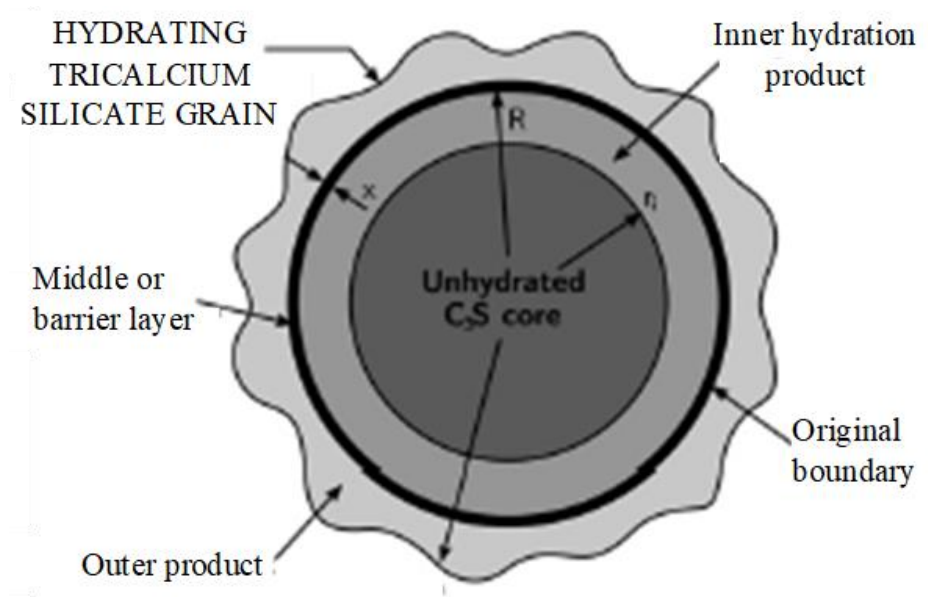

Figure 19. Schematic representation of a hydrating $C_{3} S$ (alite) grain [55].

A continuous period of slow reaction was observed after the second thermal power peak for all the blended mixtures (Figures 13-16). This was where the produced thermal powers began to level off with further hydration reaction between $\mathrm{MgO}$ and the silica/alumina present within the blended mixture composition. The further hydration reaction was quite slow for all the blend systems and can be attributed to the high magne- 
sium oxide content $\left(\mathrm{Mg}^{2+}\right.$ cations and anions), which possesses a retarding effect on the thermodynamics and kinetics of the hydration reaction [47].

Generally, the continuous trend of increase in the production of calorimetric $\mathrm{HOH}$ for the $\mathrm{MgO}$ waste:GGBS blends as a result of increased hydration could be attributed to the presence of pozzolanic materials within their compositions, which is responsible for the generation of more $\mathrm{HOH}$ at later stages [18]. In addition, this phenomenon could be attributed to the fine particles of GGBS that are required for accelerated hydration reaction kinetics by $\mathrm{MgO}$ to create more heterogeneous nucleation sites and continuous production of the hydration compound-M-S-H gel [56]. The maximum $\mathrm{HOH}$ experienced by blended mixtures with MG1 could be a result of the high reactivity levels of MG1 (type of MgO) used compared to others. However, the fall in calorimetric $\mathrm{HOH}$ that was experienced by some of the blended mixtures could be the exhaustion of the activator present within the mixture for continuous hydration reaction process and the reduced amount of water present within the mix, resulting in delayed hydration reaction kinetics [57]. Hence, the mix compositions within the MG1 and MG2 binder system exhibited potential for increased generation of $\mathrm{HOH}$ due to the superior performance from other identified blend system (MG3 and MG4).

\section{Conclusions}

The current study investigated the application of a sustainable and economically viable thermo-chemical approach using a set of experimental regimes as a tool for binder system optimization. This approach enabled a quick determination of the best performing binder systems before any civil engineering application (soil stabilisation, mortar, concrete, etc.). Therefore, the following conclusions can be drawn based on the outcomes of the study:

1 The thermochemical optimisation approach revealed the potentials of $\mathrm{MgO}$ waste materials to effectively replace PC up to $90 \mathrm{wt} . \%$ within a MgO-GGBS cementitious system and can describe the chemical and thermal performance of the investigated MgO:GGBS compositions with a set design criteria well.

2 MG1 binder systems were established as the best-performing binder system based on the superior performance of its mix compositions with respect to the set criteria (low $\mathrm{pH}$, increased levels of heat of hydration, and considerable thermal stability (weight loss) after thermal exposure).

3 The thermal investigation (TG/DTG analysis) established that blend compositions within the MG1 binder system developed the necessary cementitious endothermic peaks (loose water, gypsum, brucite, magnesite, and calcite) and demonstrated satisfactory thermal stability that will be beneficial when employed for practical applications (pavement subgrade) in regions with high temperature.

4 The reduction in the evolution of the first exothermic peak immediately after the commencement of the initial hydration reaction of the various MgO:GGBS formulations except MG4 blend systems shows their potential for the reduction of the production of initial ettringite formation, cracking, false strength, and flash setting of the hydrated blend system attributed to the first exothermic peak for in situ applications (mortar, concrete, soil stabilization, etc.).

5 The MgO:GGBS blends resulted in reduced $\mathrm{pH}$ levels compared with the control due to the reduced individual $\mathrm{pH}$ levels of the blend components (MgO and GGBS). However, MG4 with high sulphate contents and some levels of Ca could not be used in stabilising soils with sulphate contents due to the potential of forming the hydration compound (ettringite), which upon further hydration could result in swelling of the stabilised product.

Further experimental investigations are suggested for binder optimisation purposes, which could further reduce the scope of the experimental regime, give more insight into the chemical performance of the investigated material, and produce a rapid delivery of cementitious binder optimisation results. However, the main limitation to this thermochemical approach is largely due to human expertise at carrying out the various experimental 
tests and the surrounding temperature that could impact on the thermodynamics of the hydration reaction in the isothermal calorimetric analysis.

Author Contributions: Conceptualization, B.A., J.K. and J.O.; methodology, B.A.; validation, B.A., J.K. and J.O.; formal analysis, B.A.; investigation, B.A.; writing-original draft preparation, B.A.; writing-review and editing, J.K. and J.O.; visualization, B.A.; supervision, J.K. and J.O.; project administration, B.A. All authors have read and agreed to the published version of the manuscript.

Funding: This research received no external funding.

Institutional Review Board Statement: Not applicable.

Informed Consent Statement: Not applicable.

Data Availability Statement: Not applicable.

Conflicts of Interest: The authors declare no conflict of interest.

\section{References}

1. Yi, Y.; Gu, L.; Liu, S. Microstructural and mechanical properties of marine soft clay stabilized by lime-activated ground granulated blastfurnace slag. Appl. Clay Sci. 2015, 103, 71-76. [CrossRef]

2. Yi, Y.; Gu, L.; Liu, S.; Jin, F. Magnesia reactivity on activating efficacy for ground granulated blastfurnace slag for soft clay stabilisation. Appl. Clay Sci. 2016, 126, 57-62. [CrossRef]

3. Seco, A.; Miqueleiz, L.; Prieto, E.; Marcelino-Sádaba, S.; García, B.; Urmeneta, P. Sulfate soils stabilization with magnesium-based binders. Appl. Clay Sci. 2017, 135, 457-464. [CrossRef]

4. Li, W.; Ni, P.; Yi, Y. Comparison of reactive magnesia, quick lime, and ordinary Portland cement for stabilization/solidification of heavy metal-contaminated soils. Sci. Total. Environ. 2019, 671, 741-753. [CrossRef] [PubMed]

5. Li, W.; Yi, Y.; Puppala, A.J. Suppressing Ettringite-Induced Swelling of Gypseous Soil by Using Magnesia-Activated Ground Granulated Blast-Furnace Slag. J. Geotech. Geoenviron. Eng. 2020, 146, 6020008. [CrossRef]

6. Qomi, M.J.A.; Krakowiak, K.; Bauchy, M.; Stewart, K.; Shahsavari, R.; Jagannathan, D.; Brommer, D.; Baronnet, A.; Buehler, M.; Yip, S.; et al. Combinatorial molecular optimization of cement hydrates. Nat. Commun. 2014, 5, 4960. [CrossRef] [PubMed]

7. Sonat, C.; Unluer, C. Investigation of the performance and thermal decomposition of $\mathrm{MgO}$ and $\mathrm{MgO}-\mathrm{SiO} 2$ formulations. Thermochim. Acta 2017, 655, 251-261. [CrossRef]

8. Liua, H.; Dua, T.; Krishnan, N.M.A.; Li, H.; Bauchy, M. Study on the optimization of some cement based mixing binders' characteristics. Cem. Concr. Compos. 2019, 101, 5-14.

9. Roy, R.; Hinduja, S.; Teti, R. Recent advances in engineering design optimisation: Challenges and future trends. CIRP Ann. 2008, 57, 697-715. [CrossRef]

10. Peyronnard, O.; Benzaazoua, M. Alternative by-product based binders for cemented mine backfill: Recipes optimisation using Taguchi method. Miner. Eng. 2012, 29, 28-38. [CrossRef]

11. Golchin, B.; Hamzah, M.O.; Hasan, M.R.M. Optimization in producing warm mix asphalt with polymer modified binder and surfactant-wax additive. Constr. Build. Mater. 2017, 141, 578-588. [CrossRef]

12. Bayiha, B.N. Optimizing the Choice of Limestone Deposits for the Production of Portland Cement in Cameroon. Int. J. Mater. Sci. Appl. 2018, 7, 174. [CrossRef]

13. Mahmoodi, O.; Siad, H.; Lachemi, M.; Dadsetan, S.; Sahmaran, M. Optimization of brick waste-based geopolymer binders at ambient temperature and pre-targeted chemical parameters. J. Clean. Prod. 2020, 268, 122285. [CrossRef]

14. Mahmoodi, O.; Siad, H.; Lachemi, M.; Dadsetan, S.; Sahmaran, M. Development of optimized binary ceramic tile and concrete wastes geopolymer binders for in-situ applications. J. Build. Eng. 2021, 43, 102906. [CrossRef]

15. Jin, F.; Gu, K.; Al-Tabbaa, A. Strength and hydration properties of reactive MgO-activated ground granulated blastfurnace slag paste. Cem. Concr. Compos. 2015, 57, 8-16. [CrossRef]

16. Wang, F.; Jin, F.; Shen, Z.; Al-Tabbaa, A. Three-year performance of in-situ mass stabilised contaminated site soils using MgO-bearing binders. J. Hazard. Mater. 2016, 318, 302-307. [CrossRef] [PubMed]

17. Yi, Y.; Zheng, X.; Liu, S.; Al-Tabbaa, A. Comparison of reactive magnesia- and carbide slag-activated ground granulated blastfurnace slag and Portland cement for stabilisation of a natural soil. Appl. Clay Sci. 2015, 111, 21-26. [CrossRef]

18. $\mathrm{Hu}, \mathrm{J} . ; \mathrm{Ge}, \mathrm{Z}$; Wang, K. Influence of cement fineness and water-to-cement ratio on mortar early-age heat of hydration and set times. Constr. Build. Mater. 2014, 50, 657-663. [CrossRef]

19. Sedaghat, A.; Zayed, A.; Sandberg, P. Measurement and Prediction of Heat of Hydration of Portland Cement Using Isothermal Conduction Calorimetry. J. Test. Eval. 2013, 41. [CrossRef]

20. Scrivener, K.; Snellings, R.; Lothenbach, B. A Practical Guide to Microstructural Analysis of Cementitious Materials, 1st ed.; Taylor \& Francis Group: Danvers, MA, USA, 2016.

21. Mostafa, N.; Brown, P. Heat of hydration of high reactive pozzolans in blended cements: Isothermal conduction calorimetry. Thermochim. Acta 2005, 435, 162-167. [CrossRef] 
22. Schöler, A.; Lothenbach, B.; Winnefeld, F.; Ben Haha, M.; Zajac, M.; Ludwig, H.-M. Early hydration of SCM-blended Portland cements: A pore solution and isothermal calorimetry study. Cem. Concr. Res. 2017, 93, 71-82. [CrossRef]

23. BS EN 197-1:2011; Cement, Part 1: Composition, Specifications and Conformity Criteria for Common Cements; British Standards Institution: London, UK, 2011.

24. BS EN 15167-1:2006; Ground Granulated Blast Furnace Slag for Use in Concrete, Mortar and Grout. Part 1: Definitions, Specifications and Conformity Criteria; British Standards Institution: London, UK, 2006.

25. BS EN ISO 17892-4:2016; Geotechnical Investigation and Testing_Laboratory Testing of Soil. Part 4: Determination of Particle Size Distribution (ISO 17892-4:2016); British Standards Institution: London, UK, 2016.

26. Shand, M.A. The Chemistry and Technology of Magnesia; John Wiley \& Sons, Inc.: New York, NY, USA, 2006.

27. Seco, A.; Ramírez, F.; Miqueleiz, L.; García, B. Stabilization of expansive soils for use in construction. Appl. Clay Sci. 2011, 51, 348-352. [CrossRef]

28. Espuelas, S.; Omer, J.; Marcelino-Sádaba, S.; Echeverría, A.M.; Seco, A. Magnesium oxide as alternative binder for unfired clay bricks manufacturing. Appl. Clay Sci. 2017, 146, 23-26. [CrossRef]

29. BS EN ISO 787-9-2019; General Methods of Test for Pigments and Extenders. Part 9: Determination of pH Value of an Aqueous Suspension; British Standards Institution: London, UK, 2019.

30. ASTM E2550-17; Standard test method for thermal stability by thermogravimetry. In Annual Book of ASTM Standards; ASTM International: West Conshohocken, PA, USA, 2017.

31. Snelson, D.G.; Kinuthia, J.M. Resistance of mortar containing unprocessed pulverised fuel ash (PFA) to sulphate attack. Cem. Concr. Compos. 2010, 32, 523-531. [CrossRef]

32. BS EN 196-7:2007; Methods of Testing Cement. Part 7: Methods of Taking and Preparing Samples of Cement; British Standards Institution: London, UK, 2007.

33. BS EN 196-11:2018; Methods of Testing Cement. Part 11: Heat of Hydration-Isothermal Conduction Calorimetry Method; British Standards Institution: London, UK, 2018.

34. Fernandez, R.; Martirena, F.; Scrivener, K. The origin of the pozzolanic activity of calcined clay minerals: A comparison between kaolinite, illite and montmorillonite. Cem. Concr. Res. 2011, 41, 113-122. [CrossRef]

35. Bernard, E.; Lothenbach, B.; Chlique, C.; Wyrzykowski, M.; Dauzères, A.; Pochard, I.; Cau-Dit-Coumes, C. Characterization of magnesium silicate hydrate (M-S-H). Cem. Concr. Res. 2019, 116, 309-330. [CrossRef]

36. Abdalqader, A.; Jin, F.; Al-Tabbaa, A. Characterisation of reactive magnesia and sodium carbonate-activated fly ash/slag paste blends. Constr. Build. Mater. 2015, 93, 506-513. [CrossRef]

37. Walling, S.A.; Provis, J.L. Magnesia-Based Cements: A Journey of 150 Years, and Cements for the Future? Chem. Rev. 2016, 116, 4170-4204. [CrossRef]

38. Borrachero, M.V.; Paya, J.; Bonilla, M.; Monzó, J. The use of thermogravimetric analysis technique for the characterization of construction materials. J. Therm. Anal. Calorim. 2008, 91, 503-509. [CrossRef]

39. Collier, N. Transition and Decomposition Temperatures of Cement Phases-A Collection of Thermal Analysis Dat. Ceram. Silik. 2016, 338-343. [CrossRef]

40. Klein, C.; Hurlbut, J.C. Manual of Minerology; John Wiley and Sons: New York, NY, USA, 1985; Volume 20.

41. Engbrecht, D.; Hirschfeld, D. Thermal analysis of calcium sulfate dihydrate sources used to manufacture gypsum wallboard. Thermochim. Acta 2016, 639, 173-185. [CrossRef]

42. Jin, F.; Al-Tabbaa, A. Thermogravimetric study on the hydration of reactive magnesia and silica mixture at room temperature. Thermochim. Acta 2013, 566, 162-168. [CrossRef]

43. Gomes, C.M.; de Oliveira, A.D.S. Chemical phases and microstructural analysis of pastes based on magnesia cement. Constr. Build. Mater. 2018, 188, 615-620. [CrossRef]

44. Song, H.; Jeong, Y.; Bae, S.; Jun, Y.; Yoon, S.; Oh, J.E. A study of thermal decomposition of phases in cementitious systems using HT-XRD and TG. Constr. Build. Mater. 2018, 169, 648-661. [CrossRef]

45. Lanas, J.; Alvarez, J. Dolomitic lime: Thermal decomposition of nesquehonite. Thermochim. Acta 2004, 421, 123-132. [CrossRef]

46. Darko, K.; Branislav, Z. Effects of dosage and modulus of water glass on early hydration of alkali-slag cements. Cem. Concr. Res. 2002, 32, 1181-1188.

47. Amaral, L.; Oliveira, I.; Salomão, R.; Frollini, E.; Pandolfelli, V. Temperature and common-ion effect on magnesium oxide (MgO) hydration. Ceram. Int. 2010, 36, 1047-1054. [CrossRef]

48. Kuenzel, C.; Zhang, F.; Ferrándiz-Mas, V.; Cheeseman, C.; Gartner, E. The mechanism of hydration of MgO-hydromagnesite blends. Cem. Concr. Res. 2018, 103, 123-129. [CrossRef]

49. He, Y.; Lai, Z.; Yan, T.; He, X.; Lu, Z.; Lv, S.; Li, F.; Fan, X.; Zhang, H. Effect of $\mathrm{Cd}^{2+}$ on early hydration process of magnesium phosphate cement and its leaching toxicity properties. Constr. Build. Mater. 2019, 209, 32-40. [CrossRef]

50. Snelson, D.G.; Wild, S.; O'Farrell, M. Heat of hydration of Portland Cement-Metakaolin-Fly ash (PC-MK-PFA) blends. Cem. Concr. Res. 2008, 38, 832-840. [CrossRef]

51. Tydlitát, V.; Zákoutský, J.; Schmieder, M.; Černý, R. Application of large-volume calorimetry for monitoring the early-stage hydration heat development in cement-based composites as a function of w/c. Thermochim. Acta 2012, 546, 44-48. [CrossRef]

52. Moghaddam, F.; Sirivivatnanon, V.; Vessalas, K. The effect of fly ash fineness on heat of hydration, microstructure, flow and compressive strength of blended cement pastes. Case Stud. Constr. Mater. 2019, 10, e00218. [CrossRef] 
53. Bensted, J. Seventh International Congress on the Chemistry of Cement; Editions Septima: Paris, France, 1980; Volume 2, Part II, pp. 1-6.

54. Taylor, F.W.; Barret, P.; Brown, P.W.; Double, D.D.; Frohnsdorff, G.; Johansen, V.T. Materiaux et Constructions. Mater. Struct. 1984, 17, 457. [CrossRef]

55. Thomas, J.J.; Biernacki, J.J.; Bullard, J.W.; Bishnoi, S.; Dolado, J.S.; Scherer, G.; Luttge, A. Modeling and simulation of cement hydration kinetics and microstructure development. Cem. Concr. Res. 2011, 41, 1257-1278. [CrossRef]

56. Cyr, M.; Lawrence, P.; Ringot, E. Mineral admixtures in mortars and Quantification of the physical effects of inert materials on short-term hydration. Cem. Concr. Res. 2005, 35, 719-730.

57. Deboucha, W.; Leklou, N.; Khelidj, A.; Oudjit, M.N. Hydration development of mineral additives blended cement using thermogravimetric analysis (TGA): Methodology of calculating the degree of hydration. Constr. Build. Mater. 2017, 146, 687-701. [CrossRef] 